\title{
Plant Sterols the Better Cholesterol in Alzheimer's Disease? A Mechanistical Study
}

\author{
Verena K. Burg, ${ }^{1}$ Heike S. Grimm, ${ }^{1}$ Tatjana L. Rothhaar, ${ }^{1}$ Sven Grösgen, ${ }^{1}$ Benjamin Hundsdörfer, ${ }^{1}$ Viola J. Haupenthal, ${ }^{1}$ \\ Valerie C. Zimmer, ${ }^{1}$ Janine Mett, ${ }^{1}$ Oliver Weingärtner, ${ }^{4}$ Ulrich Laufs, ${ }^{4}$ Laus M. Broersen, ${ }^{5}$ Heikki Tanila, ${ }^{6}$ \\ Tim Vanmierlo, ${ }^{7}$ Dieter Lütjohann, ${ }^{7}$ Tobias Hartmann, ${ }^{1,2,3}$ and Marcus 0. W. Grimm ${ }^{1,2,3}$ \\ ${ }^{1}$ Experimental Neurology, ${ }^{2}$ Deutsches Institut für DemenzPrävention (DIDP), and ${ }^{3}$ Neurodegeneration and Neurobiology, Saarland University, and ${ }^{4}$ Clinic \\ for Internal Medicine III, Cardiology, Angiology and Intensive-Care Medicine, Saarland University Hospital, 66421 Homburg/Saar, Germany, ${ }^{5}$ Nutricia \\ Advanced Medical Nutrition, Danone Research, Centre of Specialised Nutrition, 6700 CA Wageningen, Netherlands, ${ }^{6}$ Department of Neuroscience and \\ Neurology, University of Kuopio, 70211 Kuopio, Finland, and 7Institute of Clinical Chemistry and Clinical Pharmacology, University of Bonn, 53105 Bonn, \\ Germany
}

Amyloid- $\beta(\mathrm{A} \beta)$, major constituent of senile plaques in Alzheimer's disease (AD), is generated by proteolytic processing of the amyloid precursor protein (APP) by $\beta$ - and $\gamma$-secretase. Several lipids, especially cholesterol, are associated with AD. Phytosterols are naturally occurring cholesterol plant equivalents, recently been shown to cross the blood-brain-barrier accumulating in brain. Here, we investigated the effect of the most nutritional prevalent phytosterols and cholesterol on APP processing. In general, phytosterols are less amyloidogenic than cholesterol. However, only one phytosterol, stigmasterol, reduced $\mathrm{A} \beta$ generation by (1) directly decreasing $\beta$-secretase activity, (2) reducing expression of all $\gamma$-secretase components, (3) reducing cholesterol and presenilin distribution in lipid rafts implicated in amyloidogenic APP cleavage, and by (4) decreasing BACE1 internalization to endosomal compartments, involved in APP $\beta$-secretase cleavage. Mice fed with stigmasterol-enriched diets confirmed protective effects in vivo, suggesting that dietary intake of phytosterol blends mainly containing stigmasterol might be beneficial in preventing AD.

\section{Introduction}

Alzheimer's disease (AD) is the most prevalent progressive neurodegenerative disorder in the elderly, pathologically characterized by extracellular deposition of amyloid- $\beta(\mathrm{A} \beta)$ in the brain (Glenner and Wong, 1984). A $\beta$ peptides are released by sequential proteolytic cleavage of the amyloid precursor protein (APP), a large type I transmembrane protein (Sisodia and St George-Hyslop, 2002). For the generation of A $\beta$ peptides APP is first cleaved within its ectodomain by $\beta$-secretase BACE1, generating $\beta$-secreted APP (sAPP $\beta$ ) and a C-terminal membrane-tethered fragment ( $\beta$-CTF) consisting of the $\mathrm{A} \beta$ domain and a short cytoplasmic tail (Sinha et al., 1999; Vassar et al., 1999). $\beta$-CTF is subsequently cleaved within its transmembrane domain by $\gamma$-secretase, releasing $\mathrm{A} \beta$ peptides. $\gamma$-secretase has been identified as a heterotetrameric protein

\footnotetext{
Received April 9, 2013; revised July 31, 2013; accepted Aug. 26, 2013.

Author contributions: T.H. and M.O.W.G. designed research;V.K.B., T.L.R., S.G., B.H., V.J.H., V.C.Z., J.M., H.T., T.V., and D.L. performed research; O.W., U.L., L.M.B., H.T., T.V., and D.L. contributed unpublished reagents/analytic tools; V.K.B., H.S.G., T.L.R., S.G., B.H., V.J.H., V.C.Z., J.M., and M.O.W.G. analyzed data; H.S.G., T.H., and M.O.W.G. wrote the paper.

The research leading to these results has received funding from the EU FP7 project LipiDiDiet, Grant Agreement No 211696 (T.H.), the DFG (T.H.), the Bundesministerium für Bildung, Forschung, Wissenschaft und Technologie via NGFNplus and KNDD (T.H.), and the HOMFOR (M.O.W.G.) and HOMFOR excellence (M.O.W.G.). We thank Inge Tomic and Anja Kerksiek for technical assistance.

The authors declare no conflicts of interest.

Correspondence should be addressed to Marcus 0.W. Grimm, Kirrberger Strasse 1, Gebäude 61.4, 66421 Homburg, Germany. E-mail: marcus.grimm@uks.eu.

DOI:10.1523/JNEUROSCI.1506-13.2013

Copyright $\odot 2013$ the authors $\quad 0270-6474 / 13 / 3316072-16 \$ 15.00 / 0$
}

complex and consists of at least four proteins: Presenilin 1 (PS1) or presenilin 2 (PS2), which constitute the active site of the protease, nicastrin (NCSTN), anterior pharynx-defective 1 (APH1A and APH1B), and presenilin enhancer 2 (PEN2) (De Strooper, 2003; Kimberly et al., 2003).

As $\gamma$-secretase has peculiar intramembrane proteolysis activity and all APP cleaving proteases and APP itself are integral membrane proteins, alterations in the lipid composition of cellular membranes are discussed to influence proteolytic processing of APP (Grimm et al., 2005, 2011b, 2012; Osenkowski et al., 2008; Lemkul and Bevan, 2011). However, previous studies mainly focused on cholesterol, which has been associated with AD pathogenesis (Corder et al., 1993; Kivipelto et al., 2001; Wolozin, 2001; Puglielli et al., 2003). High cholesterol level have been shown to increase $A \beta$ generation whereas suppression of cholesterol de novo synthesis strongly reduces $\mathrm{A} \beta$ release in vivo and in vitro (Fassbender et al., 2001; Refolo et al., 2001; Shie et al., 2002; Ghribi et al., 2006). Cholesterol is an essential component of cellular membranes and is highly enriched in detergentresistant membrane microdomains, called lipid rafts (Simons and Ikonen, 1997), which have been implicated in amyloidogenic APP processing (Ehehalt et al., 2003; Vetrivel and Thinakaran, 2010). Phytosterols are the naturally occurring cholesterolequivalents in plants and are contained in dietary sources like nuts, seeds, legumes, and unrefined plant oils (Weihrauch and Gardner, 1978; Piironen et al., 2000). Plant sterols reduce intestinal resorption of cholesterol and are able to cross the bloodbrain barrier and accumulate in the brain (Vanmierlo et al., 


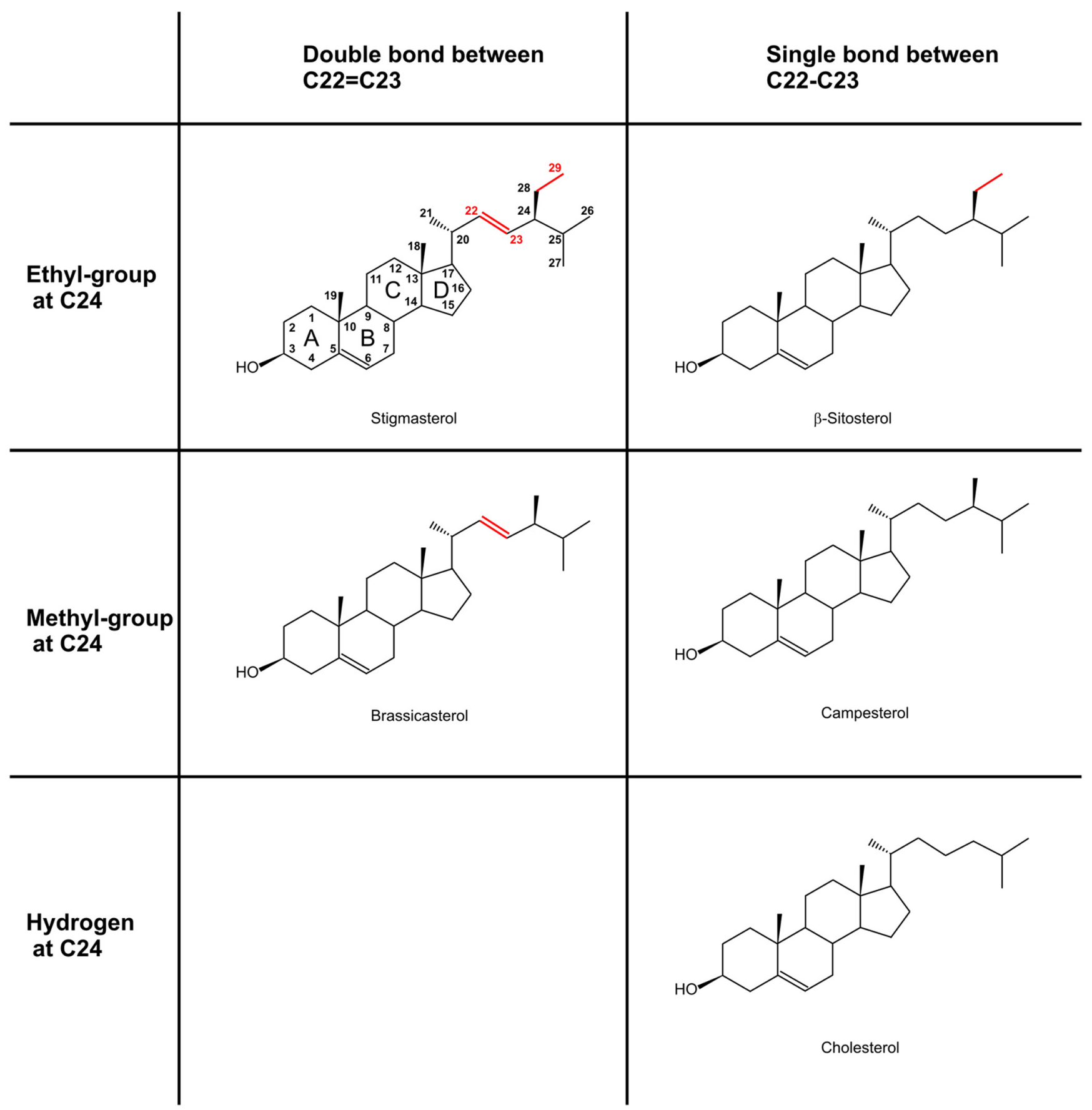

Figure 1. Chemical structure of stigmasterol, brassicasterol, $\beta$-sitosterol, campesterol, and cholesterol.

2012). They have a structure very similar to cholesterol with some modifications in the acyl chain, containing an additional double bond at C-atom C22-C23 $(\Delta 22)$ or an alkyl-group (methyl- or ethyl-group) at C24 (Fig. 1). Due to their structural similarity to cholesterol, plant sterols may interfere with cholesteroldependent cellular processes in the brain. Furthermore, plant sterols have also been shown to be organized in lipid rafts within plant cell membranes (Mongrand et al., 2004, 2010) and might therefore alter amyloidogenic processing of APP. In the present study we investigated the influence of the most prevalent plant sterols-stigmasterol, brassicasterol, $\beta$-sitosterol, and campesterol (Gunstone et al., 1994; Dufourc, 2008) —and cholesterol on the amyloidogenic proteolytic cleavage of APP.

\section{Materials and Methods}

\section{Chemical reagents and sterols}

Unless otherwise indicated, all chemical reagents and sterols were obtained from Sigma Aldrich and were from the highest commercially available purity.

\section{Animals}

Eighteen male, nine-week-old C57BL/6J mice were obtained from Charles River. The animals were kept in groups of six animals per cage. The environmental parameters were adjusted to a temperature at $20-22^{\circ} \mathrm{C}$, humidity at $50-60 \%$, and lights on for $12 \mathrm{~h}$ every day. Water and food were available ad libitum throughout this study.

All experiments were performed in accordance with Dutch laws governing the use of laboratory animals. 
The diets were AIN-93M-based (Reeves et al., 1993) and obtained from Research Diet Services. Total fat-content was adjusted to $5 \%$ in all diets. Animals were fed 4-6 weeks with one of three isocaloric diets. Next to the control diet, stigmasterol-enriched diets containing $0.19,0.25$, or $0.39 \%$ of stigmasterol (CarboMer) were administered.

After administration of the diet, animals were killed by $\mathrm{CO}_{2}$ gas inhalation and decapitation by guillotine. Brains were quickly removed from the scull, snapfrozen in liquid nitrogen, and stored at $-80^{\circ} \mathrm{C}$ until analysis.

Brains were homogenized either in $2 \mathrm{ml}$ of aqua destillata or $4 \times$ volume of lysis buffer (50 mM Tris/HCl pH7.4, 1\% NP-40, 0.25\% sodiumdesoxycholat, $150 \mathrm{~mm} \mathrm{NaCl}, 1 \mathrm{~mm}$ EDTA, $1 \times$ protease inhibitor cocktail containing AEBSF, Calbiochem) using a Teflon homogenizer.

\section{Cell culture and sterol treatment}

Human neuroblastoma SH-SY5Y wt cells and SH-SY5Y cells, stably transfected with human APP695 or SPC99 (Grimm et al., 2003), were cultivated as described previously (Grimm et al., 2011b). Cells were cultured until they attained confluence. Sixteen hours before sterol treatment, serum in the culture medium was reduced $(0.1 \%$ FBS). Plant sterols and cholesterol were used at a final concentration of $10 \mu \mathrm{M}$ and were incubated for $8 \mathrm{~h}+16 \mathrm{~h}$ in serum-reduced culture medium containing $0.1 \%(\mathrm{w} / \mathrm{v})$ fatty acid free BSA. In controls, solvent ethanol was adjusted to $1 \%$, according to solvent content in sterol-treated cells.

\section{Antibodies}

For Western blot (WB) analysis, the following antibodies were used: anti-presenilin1 sc7860, 1:500 (Santa Cruz Biotechnology), human antiBACE1 B0806, 1: 1000 (Sigma Aldrich), mouse anti-BACE PC529, 1:1000 (Calbiochem), anti-flotillin 610821, 1:250 (BD Biosciences), anticadherin ab6528, 1:1000 (Abcam), anti-actin ab1801, 1:2000 (Abcam), anti-EEA1 ab2900, 1:1000 (Abcam), anti-APP/anti- $\beta$ CTF/anti-A $\beta$ W02, $1 \mu \mathrm{g} / \mathrm{ml}$ (Ida et al., 1996) As secondary antibodies, anti-rabbit-HRP W401B, 1:5000 (Promega) and anti-mouse-HRP 1:5000 (DAKO) were used. Proteins were detected using ECL-method. Data are presented as percentage of density compared with solvent control. Densiometric quantification was performed with Image Gauge software. As control for the determination of BACE1 and PS1 protein level in presence of plant sterols or cholesterol, we analyzed protein level of actin, which was unchanged in presence of sterols (Fig. 2E).

\section{Constructs and transient transfection of secreted alkaline phosphatase}

For transient transfection of SH-SY5Y wt cells, expression vector pVectOZ-secreted alkaline phosphatase (SEAP; OZ Biosciences) was used at $1 \mu \mathrm{g} /$ transfection. Lipofectamine 2000 (Invitrogen) was used as transfection reagent at $1.5 \mu \mathrm{l} /$ transfection. Briefly, cells were washed once with OptiMEM + GlutaMAX serum-reduced medium (Invitrogen), and DNA/Lipofectamine complexes were incubated for $5 \mathrm{~h}$ in OptiMEM + GlutaMAX. After transfection, medium was removed and cells were cultured in growth medium (DMEM, 10\% FBS, $1 \times$ MEM) for $48 \mathrm{~h}$. Subsequently, cells were treated with plant sterols like described before.

\section{SEAP-assay}

Culture media were collected after plant sterol treatment of SEAPtransfected SH-SY5Y cells. Samples were centrifuged at $3000 \mathrm{rpm}$ at $4^{\circ} \mathrm{C}$ and boiled at $65^{\circ} \mathrm{C}$ for $10 \mathrm{~min}$, and $100 \mu \mathrm{l}$ sample was analyzed in a 96-well plate after adding $100 \mu \mathrm{l}$ of 1-Step PNPP solution (Thermo Scientific) by monitoring OD405 $\mathrm{nm}$. SEAP expression was shown to be detectable at least for $96 \mathrm{~h}$ after transfection in SH-SY5Y cells. To exclude variations in SEAP secretion due to heterogeneous transfection, SEAP secretion was also monitored before plant sterol treatment of the cells.

\section{Determination of protein concentration}

Protein determination was performed according to Smith et al. (1985).

\section{Detection of secreted $A \beta$}

Generation of conditioned media and detection of secreted $A \beta$ of steroltreated cells was performed as described previously (Grimm et al., 2003).

\section{Determination of $A \beta 40$ and $A \beta 42$ by ELISA}

Levels of soluble $A \beta$ in brains of stigmasterol-fed mice were determined using a commercially available ELISA Kit (Mouse A $\beta$ ELISA Kit, Invitrogen) according to manufacturer's protocol. Mouse brains were weighted and homogenized in $4 \times$ volume of lysis buffer $(50 \mathrm{~mm}$ Tris/ $\mathrm{HCl}$ pH7.4, 1\% NP-40, 0.25\% sodium-desoxycholat, $150 \mathrm{~mm} \mathrm{NaCl}, 1$ mM EDTA, $1 \times$ protease inhibitor cocktail containing AEBSF, Calbiochem). Homogenates were incubated on ice for $15 \mathrm{~min}$ and centrifuged for $10 \mathrm{~min}$ at $3000 \mathrm{rpm}$ at $4^{\circ} \mathrm{C}$. Supernatant was removed and pellet was solubilized in lysis buffer containing protease inhibitors using a 24 gauge $\times 1$ " needle. Samples were incubated on ice for $90 \mathrm{~min}$, followed by a centrifugation at $13,000 \mathrm{rpm}$ at $4^{\circ} \mathrm{C}$ for $20 \mathrm{~min}$. Supernatants, containing soluble $\mathrm{A} \beta$ peptides, were transferred to a new tube and protein concentration was determined as described. Samples were diluted 1:2 in standard dilution buffer (kit content) and $225 \mu \mathrm{g} / 100 \mu \mathrm{l}$ was used for each assay. $A \beta$ in mouse brains was calculated at means of a serial dilution of mouse synthetic peptide and were presented as $\mathrm{pg} / \mathrm{mg}$ wet weight tissue.

Level of $A \beta 40$ and $A \beta 42$ in cell culture supernatant of stigmasterolincubated SH-SY5Y cells stably expressing human APP695 were determined using commercially available ELISA Kits (Human A $\beta$ ELISA Kits KHB3481/KHB3544, Invitrogen) according to manufacturer's protocol. Samples were diluted in standard dilution buffer and the linear range of the ELISA was verified by a serial dilution of synthetic peptides.

\section{Preparation of cell lysates}

After washing cells three times with ice-cold PBS, cells were scraped off in PBS, containing complete protease inhibitor cocktail (Roche). Cells were centrifuged at $13,000 \mathrm{rpm}$ for $10 \mathrm{~min}$ at $4^{\circ} \mathrm{C}$. Supernatant was removed and cells were lysed with $75 \mu \mathrm{l}$ of lysis buffer (50 mM Tris/HCl pH7.4, $1 \%$ NP-40, 0.25\% sodium-desoxycholat, $150 \mathrm{~mm} \mathrm{NaCl}, 1 \mathrm{~mm}$ EDTA, complete protease inhibitor cocktail) and solubilized using a $23 \times$ gauge needle. Samples were centrifuged again at $13,000 \mathrm{rpm}$ for $10 \mathrm{~min}$ at $4^{\circ} \mathrm{C}$ and supernatants were used for further analysis. Protein concentrations were determined as described. Samples were adjusted to equal protein amounts $(60 \mu \mathrm{g})$ and were used for the analysis of BACE1 and PS1 protein levels.

\section{In vitro and ex vivo determination of secretase activities}

Activities of $\beta$ - and $\gamma$-secretase were measured either in vitro in postnuclear fractions (PNFs) of SH-SY5Y wt cells or ex vivo in brain PNFs of C57BL/6 mice in presence of plant sterols, cholesterol, or solvent control in at least four independent experiments (implying independent sterol-treatments/PNF, each analyzed in triplicate, $n \geq 4)$. Additionally, $\beta$ - and $\gamma$-secretase activities were determined in brain homogenates of six stigmasterol-fed mice, compared with six mice, fed with control diet $(n=6)$.

\section{Preparation of postnuclear fractions}

Confluent SH-SY5Y wt cells were cultured for $48 \mathrm{~h}$ in incubation medium (DMEM, 0.1\% FBS, 1\% MEM). Medium was changed after $24 \mathrm{~h}$. Briefly, cells were harvested and cells or mouse brains were homogenized in EDTA-sucrose buffer (10 mM Tris-HCl pH7.4, $1 \mathrm{~mm}$ EDTA, $200 \mathrm{~mm}$ sucrose). Samples were adjusted to a protein concentration of $2 \mathrm{mg} / \mathrm{ml}$ and centrifuged at $900 \mathrm{rpm}$ for $10 \mathrm{~min}$ at $4^{\circ} \mathrm{C}$. Postnuclear supernatants were transferred in a new tube and stored at $-80^{\circ} \mathrm{C}$ until analysis.

Treatment of postnuclear fractions with plant sterols/cholesterol Postnuclear fractions (PNFs) of SH-SY5Y cells or C57BL/6 mouse brains were transferred in a glass tube and plant sterols or cholesterol were added to a final concentration of $50 \mathrm{nMol} / \mathrm{mg}$ protein. All samples contained equal solvent concentrations ( $1 \%$ ethanol). Samples were incubated for $15 \mathrm{~min}$ at $37^{\circ} \mathrm{C}$ in a Heidolph Multi Reax Shaker (Heidolph Instruments $\mathrm{GmbH}$ and $\mathrm{Co}$. $\mathrm{KG}$ ) at maximum speed.

\section{Preparations of total membranes}

After incubation of PNFs, total membranes were prepared by centrifugation at 55,000 rpm for $75 \mathrm{~min}$ at $4^{\circ} \mathrm{C}$ in an Optima MAX Ultracentrifuge using a TLA-55 rotor (Beckmann Coulter). The resulting pellet was 
A

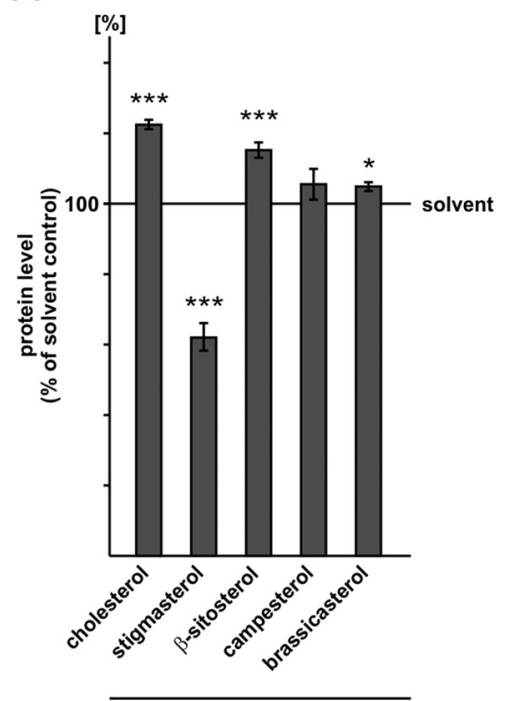

A $\beta$ (SH-SY5Y APP695)

D

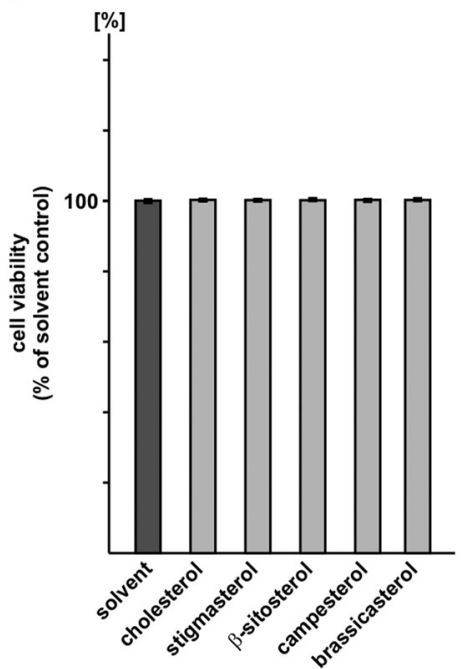

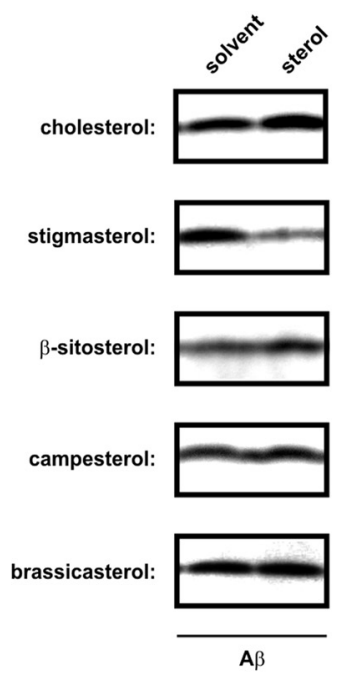

B

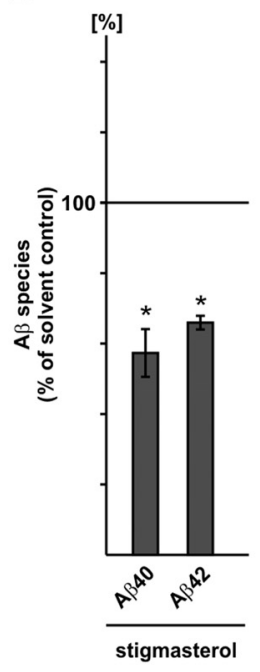

$\mathrm{E}$
C

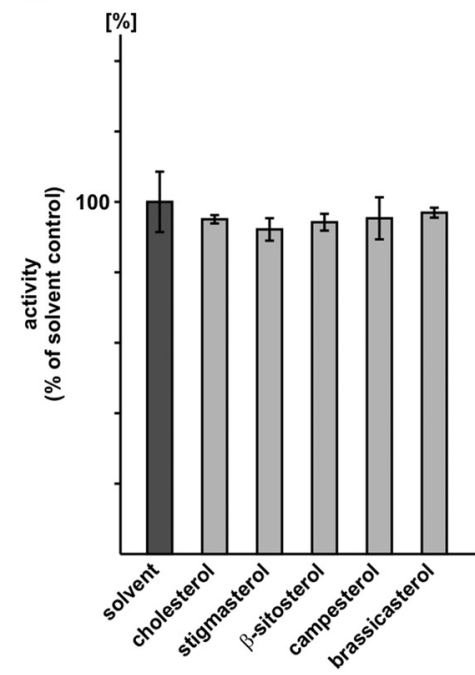

$\overline{\text { secretory alkaline phosphatase }}$

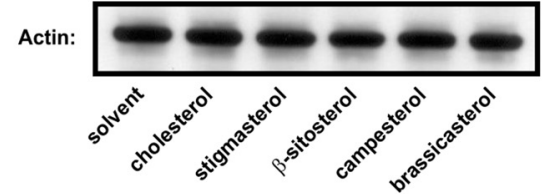

Figure 2. Effect of plant sterols and cholesterol on A $\beta$ secretion. $\boldsymbol{A}$, Human neuroblastoma SH-SY5Y cells stably transfected with APP695 were incubated with stigmasterol, $\beta$-sitosterol, campesterol, brassicasterol, or cholesterol (final concentration, $10 \mu \mathrm{M}$ ) and solvent control. Immunoprecipitation of secreted A $\beta$ and WB analysis was performed with antibody W02. Representative WBs are shown. Error bars represent SD of the mean. $\boldsymbol{B}$, Determination of A $\beta 40$ and A $\beta 42$ peptides in stigmasterol-treated APP695 transfected SH-SY5Y cells using ELISA technique. C, Determination of SEAP activity in presence of sterols $(10 \mu \mathrm{M})$ in SH-SY5Y cells transiently transfected with SEAP. D, Lactate dehydrogenase assay in cells incubated with cholesterol, stigmasterol, $\beta$-sitosterol, campesterol, and brassicasterol in a final concentration of $10 \mu \mathrm{m}$ compared with solvent control. No signs for increased cytotoxicity were observed in cells treated with sterols. Asterisks show the statistical significance compared with control $\left({ }^{*} p \leq 0.05 ;{ }^{* *} p \leq 0.01 ;{ }^{* * *} p \leq 0.001\right)$. Quantified data represent an average of at least three independent experiments $(n \geq 3)$. $\boldsymbol{E}$, Representative WB analysis of actin protein level in SH-SY5Y cells incubated with plant sterols and cholesterol (final concentration of $10 \mu \mathrm{M}$ ).

resuspended in the corresponding EDTA-sucrose buffer. In all cases, the pellet was resolubilized by passing the sample through needles with decreasing diameters $(0.6 \mathrm{~mm}, 0.4 \mathrm{~mm}, 0.33 \mathrm{~mm})(\mathrm{BD})$.

\section{Measurement of secretase activities}

Activities of either $\beta$ - or $\gamma$-secretase were determined in a black 96-well plate (BD) by continuous measurement of the cleavage of a specific substrate in a Safire ${ }^{2}$ Fluorometer (Tecan), resulting in an increasing fluorescent signal. For the assay of $\gamma$-secretase, $100 \mu \mathrm{l}$ of sample was used, corresponding to $250 \mu \mathrm{g}$ of total protein for SH-SY5Y wt cells and $500 \mu \mathrm{g}$ for mouse brain homogenates. $\gamma$-secretase substrate (Calbiochem) was added to a final concentration of $10 \mu \mathrm{M}$. Measurement parameters were adjusted to an excitation wavelength of $355 \mathrm{~nm}$ (bandwidth $10 \mathrm{~nm}$ ) and an emission wavelength of $440 \mathrm{~nm}$ (bandwidth $10 \mathrm{~nm}$ ). Kinetic measurement was performed for 50 cycles with intervals of $180 \mathrm{~s}$. For the determination of $\gamma$-secretase activity in lipid rafts and nonraft gradient fractions, $100 \mu$ l of each fraction was used.
For determination of $\beta$-secretase activity, samples were diluted 1:1 in PBS, pH4.5, and $100 \mu \mathrm{l}$ of this dilution was used for the assay, corresponding to $125 \mu \mathrm{g}$ of total protein for SH-SY5Y wt cells and $250 \mu \mathrm{g}$ for mouse brain homogenates. The $\beta$-secretase substrate IV (Calbiochem) was used at a final concentration of $20 \mu \mathrm{M}$. Measurement parameters were adjusted to an excitation wavelength of $345 \mathrm{~nm}$ (bandwidth $5 \mathrm{~nm}$ ) and an emission wavelength of $500 \mathrm{~nm}$ (bandwidth $10 \mathrm{~nm}$ ). Kinetic was performed for 180 cycles with intervals of $60 \mathrm{~s}$.

\section{Quantitative real-time PCR}

Total RNA extraction and real-time PCR (RT-PCR) was performed as described previously (Grimm et al., 2011a). The following primer sequences were used:

Aphla: 5'-CAG CCA TTA TCC TGC TCC AT-3' and 5'-GGA ATG TCA GTC CCG ATG TC-3'; Aph1b: 5' -GTG TCA GCC CAG ACC TTC AT-3' and 5'-CAG GCA GAG TTT CAG GCT TC-3'; Bace1: 5'-AAT ACC TGC GGT GGA AGA TG-3' and 5'-GCC CTC CAT GAT AAC 
AGC TC-3' ${ }^{\prime}$ N Ncstn: $5^{\prime}$-CTG TAC GGA ACC AGG TGG AG-3' and 5' GAG AGG CTG GGA CTG ATT TG-3'; Psen1: $5^{\prime}$-CTC AAT TCT GAA TGC TGC CA- $3^{\prime}$ and $5^{\prime}$-GGC ATG GAT GAC CTT ATA GCA- $3^{\prime}$; Psen2: 5'-GAT CAG CGT CAT CGT GGT TA- $3^{\prime}$ and $5^{\prime}$-GGA ACA GCA GCA TCA GTG AA- $3^{\prime}$; Psenen $2: 5^{\prime}$-CAT CTT CTG GTT CTT CCG AGA G-3' and $5^{\prime}$-AGA AGA GGA AGC CCA CAG C- ${ }^{\prime}$; $\beta$-actin: $5^{\prime}$-CTT CCT GGG CAT GGA GTC-3' and 5' -AGC ACT GTG TTG GCG TAC AG-3'.

\section{Lipid raft preparation}

Lipid rafts were prepared as described previously using Triton X-100 and ultracentrifugation method (Grimm et al., 2011b).

\section{Cholesterol distribution in lipid rafts}

Confluent SH-SY5Y wt cells were washed two times with incubation medium (DMEM, 0.1\% FBS, $1 \%$ MEM) and preincubated for $4 \mathrm{~h}$ under serum-reduced conditions. After this, cells were pulsed for $16 \mathrm{~h}$ with 0.4 $\mu \mathrm{Ci} / \mathrm{ml}\left[{ }^{14} \mathrm{C}\right]$-cholesterol $(45-60 \mathrm{mCi} / \mathrm{mmol}$, PerkinElmer) in incubation medium. Subsequent to cholesterol treatment, cells were incubated with plant sterols like described before. Lipid rafts were prepared as described previously (Grimm et al., 2011b) and distribution of incorporated $\left[{ }^{14} \mathrm{C}\right]$-cholesterol in collected fractions was determined via liquid scintillation counting in a Tri-Carb2800TR (PerkinElmer).

\section{Preparation of endosomal fractions}

Endosomal fractions were prepared with OptiPrep (Iodixanol; AxisShield) density gradient centrifugation according to Woods et al. (2004) with minor modifications. After incubation with stigmasterol, cells were washed with ice-cold PBS and homogenized in sucrose buffer containing $140 \mathrm{~mm} \mathrm{NaCl}, 1 \mathrm{~mm}$ EDTA, and $20 \mathrm{~mm}$ Tris/HCl, pH 8,0, using a PotterS (Braun). For WB analysis of APP, Bace1 and $\beta$-CTF in endosomal fractions sucrose buffer additionally contains complete protease inhibitor cocktail. Cell debris and nuclei were removed by centrifugation at $800 \times$ $g$ for $5 \mathrm{~min}$. Gradient solutions with 10, 20, 30, and 40\% iodixanol were made by diluting $60 \%$ Iodixanol stock solution with dilution buffer containing $250 \mathrm{~mm}$ sucrose, $140 \mathrm{~mm} \mathrm{NaCl}, 3 \mathrm{~mm}$ EDTA, and $60 \mathrm{~mm}$ Tris/ $\mathrm{HCl}$, $\mathrm{pH} 8,0$. A discontinuous $10-40 \%$ density gradient was prepared with 2.5 $\mathrm{ml}$ layers of each solution in $13.2 \mathrm{ml}$ ultracentrifugation tubes (Beckman Coulter). Tubes were turned in a horizontal position for $1 \mathrm{~h}$ at room temperature (RT), resulting in a continuous gradient. One milliliter of postnuclear fraction containing $5 \mathrm{mg}$ of protein was layered on top of each gradient and gradients were centrifuged for $18 \mathrm{~h}$ at $48,000 \times g$ at $4^{\circ} \mathrm{C}$ in a swinging-bucket rotor (SW41, Beckman Coulter). Gradients were unloaded from the top collecting 20 fractions à $550 \mu$ l. Endosomal fractions were identified by WB with anti-EEA1 antibody (ab2900, Abcam). Early endosomal antigen 1 (EEA1)-positive fractions were pooled for further analyzing $\beta$-secretase activity, BACE1, and $\beta$-CTF protein levels.

\section{Cell surface biotinylation}

Cells were cultivated until confluence on $10 \mathrm{~cm}$ cell culture dishes. After incubation with stigmasterol, cells were washed three times with ice-cold PBS containing $1 \mathrm{~mm} \mathrm{MgCl} 2$ and $0.1 \mathrm{mM} \mathrm{CaCl}_{2}$ (PBS/CM), scraped off, and incubated in PBS/CM supplemented with $0.5 \mathrm{mg} / \mathrm{ml} \mathrm{EZ-Link} \mathrm{Sulfo-}$ NHS-LC-Biotin (Pierce) for $30 \mathrm{~min}$ at $4^{\circ} \mathrm{C}$ with rotating. Cells were washed once with PBS/CM and biotinylation was quenched with a 100 mM glycine/PBS wash, followed by three washes with PBS/CM. After lysis, samples were centrifuged with $14,500 \mathrm{rpm}$ for $15 \mathrm{~min}$ at $4^{\circ} \mathrm{C}$ and biotinylated proteins were immunoprecipitated with $100 \mu \mathrm{l}$ of $50 \%$ streptavidin agarose (Pierce) overnight at $4^{\circ} \mathrm{C}$. After washing three times with lysis buffer, proteins were eluted by boiling for $5 \mathrm{~min}$ in $3 \times$ SDS sample buffer (187.5 mm Tris/HCl pH6.8, 6\% SDS, 30\% glycerol, $15 \%$ $\beta$-mercaptoethanol, $0.03 \%$ bromphenol blue) and analyzed by WB as described above.

Determination of cholesterol and plant sterol uptake in SH-SY5Y cells and membrane microdomains after treatment

Sample preparation. Cells were harvested and homogenized by ultrasound treatment ( $30 \mathrm{~s}, 50 \%$ intensity) and adjusted to $175 \mu \mathrm{g} / 20 \mu \mathrm{l}$ aqua destillata. For sterol-determination in membrane microdomains, fractions 6-9 (raft) and fractions 12-16 (nonraft) were pooled. Lipids were extracted using a modified method according to Bligh and Dyer (1959).
Sterol extraction. As internal standard, cholesterol (D7, $5 \mu \mathrm{g} / \mathrm{sample}$; Avanti Polar Lipids) was added. One-hundred microliters of dry 1,4dioxane was added to each sample. The samples were mixed, sonicated for $10 \mathrm{~s}$, and dried in a vacuum concentrator. For sterol extraction, samples were resolubilized in $50 \mu \mathrm{l}$ of 1,4-dioxane, sonicated, and centrifuged at $20,800 \times g$ for $20 \mathrm{~min}$ at $15^{\circ} \mathrm{C}$. Resulting supernatants were transferred in new microcentrifuge tubes and dried in a vacuum concentrator.

Derivatization. Sterols were derivatized by a method from the study by Duff (1949). Briefly, $20 \mu \mathrm{l}$ of a freshly prepared sulfur trioxide pyridine complex solution $(25 \mathrm{mg}$ of sulfur trioxide pyridine complex in $5 \mathrm{ml}$ of pyridine) was added to the samples and sonicated for $10 \mathrm{~s}$. The derivatization reaction was performed for $30 \mathrm{~min}$ at $\mathrm{RT}$, followed by addition of $2.1 \mu \mathrm{l}$ of barium acetate solution $(314.1 \mathrm{~mm})$. The samples were sonicated for $10 \mathrm{~s}$ and incubated for $10 \mathrm{~min}$ at RT followed by $60 \mathrm{~min}$ at $4^{\circ} \mathrm{C}$. Finally, $120 \mu \mathrm{l}$ of methanol was added and samples were centrifuged at $20,800 \times g$ for $10 \mathrm{~min}$ at $15^{\circ} \mathrm{C}$. Supernatants were transferred into a 96-deep well plate (Nunc), $600 \mu \mathrm{l}$ of methanol was added to each sample, and sterols were analyzed by mass spectrometry.

Mass spectrometry. Mass spectrometry analyses were performed with a 4000 quadrupole linear-ion trap (QTrap) with a Turbo Spray ion source (AB SCIEX) connected to a 1200 Agilent HPLC (Agilent). Twenty microliters of each sample was injected and precursor ion scan (negative mode) with $\mathrm{m} / \mathrm{z} 97$ set as precursor ion (loss of $\mathrm{HSO}_{4}^{-}$) was performed using the following HPLC gradient: Step 0: $0.00 \mathrm{~min} ; 30 \mu \mathrm{l} / \mathrm{min}$; water/ methanol (3/97; v/v). Step 1: $1.60 \mathrm{~min} ; 30 \mu \mathrm{l} / \mathrm{min}$; water/methanol (3/97; v/v), Step 2: $2.40 \mathrm{~min} ; 200 \mu \mathrm{l} / \mathrm{min}$; water/methanol (3/97; v/v). Step 3: $2.80 \mathrm{~min} ; 200 \mu \mathrm{l} / \mathrm{min}$; water/methanol (3/97; v/v). Step 4: $3.00 \mathrm{~min} ; 30$ $\mu \mathrm{l} / \mathrm{min}$; water/methanol (3/97; v/v). The method properties were set as following: Curtain Gas (CUR): 10.0; Collision Gas (CAD): Medium; Ionspray voltage (IS): -4500.00 and Ion source gas (GS1): 19.0. For each spectrum $(\mathrm{m} / \mathrm{z} 400-500) 50$ repetitive scans with duration of $3 \mathrm{~s}$ each were averaged. For quantification of sterol-sulfates from treated cells, the following $\mathrm{m} / \mathrm{z}$-values were used: cholesterol-sulfate $465.3 \mathrm{~m} / \mathrm{z}$; stigmasterol-sulfate $491.3 \mathrm{~m} / \mathrm{z}$; brassicasterol-sulfate $477.3 \mathrm{~m} / \mathrm{z}$; campesterol-sulfate $479.3 \mathrm{~m} / \mathrm{z} ; \beta$-sitopsterol-sulfate $493.3 \mathrm{~m} / \mathrm{z}$; cholesterol(D7)sulfate (standard) $472.3 \mathrm{~m} / \mathrm{z}$.

\section{Sterol extraction and determination in brain and serum samples of stigmasterol-fed mice}

Samples were frozen and stored at $-80^{\circ} \mathrm{C}$ until analysis. Cholesterol and stigmasterol were extracted from brain and serum using chloroformmethanol and analyzed after derivatization.

Cholesterol content in brains and serum of stigmasterol-fed mice and control mice was determined by gas chromatography-flame ionization detection (GC-FID) as previously described (Kölsch et al., 2010). Stigmasterol content of the same samples was analyzed by a method of combined gas chromatography and mass spectrometry (GC-MS-SIM). Both techniques were performed as previously described (Teunissen et al., 2003; Kölsch et al., 2010). Cholesterol content was determined by means of $5 \alpha$-cholestan as internal standard and stigmasterol levels by means of epicoprostanol.

\section{Gas chromatography-flame ionization detection}

Plasma and brain cholesterol was analyzed on a HP 6890 seriesII plus GC (Agilent Technologies). As an internal standard, $5 \alpha$-cholestane was used. Briefly, samples were injected in a splitless mode at $280^{\circ} \mathrm{C}$, using an injector (HP 7683) and hydrogen as carrier gas (inlet pressure 9.9 psi, total gas-flow $1.1 \mathrm{ml} / \mathrm{min}$ ). For separation of sterols, a cross-linked methyl-silicone DB-XLB 122-1232 fused silica capillary column (J\&W; $30 \mathrm{~m} \times 0.25 \mathrm{~mm}$ and $0.25 \mu \mathrm{m}$ film thickness) was used. The initial temperature of $150^{\circ} \mathrm{C}$ was kept for $3 \mathrm{~min}$ and then increased stepwise at $30^{\circ} \mathrm{C}$ to reach a final temperature of $290^{\circ} \mathrm{C}$. For determination of absolute cholesterol concentrations, ratios of cholesterol areas to areas of the internal standard $5 \alpha$-cholestane were defined and multiplied by the amount of $5 \alpha$-cholestane ( $50 \mu \mathrm{g}$ ), added to a defined sample volume.

\section{GC-MS-SIM}

The technique was performed on a HP GC-MSD system (HP 5890, series II GC) in combination with a 5971 mass selective detector (Agilent Tech- 
nologies). Briefly, samples were injected in the splitless mode with helium as carrier gas (flow rate $1 \mathrm{ml} / \mathrm{min}$ ). The sterols were separated on a DB-XLB 122-1232 fused silica capillary column (J\&W; $30 \mathrm{~m} \times 0.25 \mathrm{~mm}$ and $0.25 \mu \mathrm{m}$ film thickness). A temperature of $150^{\circ} \mathrm{C}$ was initially kept at $150^{\circ} \mathrm{C}$ for $1 \mathrm{~min}$, followed by a stepwise increase at $20^{\circ} \mathrm{C} / \mathrm{min}$ to $260^{\circ} \mathrm{C}$, followed by $10^{\circ} \mathrm{C} / \mathrm{min}$ to $280^{\circ} \mathrm{C}$.

Stigmasterol and epicoprostanol (internal standard) were monitored as their TMSi derivates in the selected ion monitoring mode, based on following masses: stigmasterol $\mathrm{m} / \mathrm{z} 484\left[\mathrm{M}^{+}\right]$and epicoprostanol (internal standard) $\mathrm{m} / \mathrm{z} 370\left[\mathrm{M}^{+}\right.$-OTMSi]. Stigmasterol was analyzed from selected ion monitoring analysis against internal standard epicoprostanol using standard curves. The identity of sterols was validated by the use of additional qualifier ions, as well as comparison with full-scan mass spectra of authentic compound ( $/ \mathrm{z} / \mathrm{z} 5-500)$.

\section{Statistical analysis}

All quantified data represent an average of at least three independent experiments. Statistical significance was determined by two-tailed Student's $t$ test.

\section{Results}

\section{Effect of plant sterols and cholesterol on $\mathrm{A} \beta$ secretion}

To analyze whether the nutritional most relevant plant sterols affect amyloidogenic processing of APP, we incubated human neuroblastoma SH-SY5Y cells with stigmasterol $(\Delta 22$, ethyl group at C24), $\beta$-sitosterol (ethyl group at C24), brassicasterol $(\Delta 22$, methyl group at C24) and campesterol (methyl group at C24) (Fig. 1). To validate potential effects found by plant sterols, we used cholesterol throughout our study as the impact of cholesterol on APP processing has been at least in some respect already intensively investigated.

For the detection of secreted A $\beta$ levels we used SH-SY5Y cells stably transfected with APP695, the predominant APP isoform in neurons (Rohan de Silva et al., 1997). As expected cholesterol significantly increased $\mathrm{A} \beta$ levels $(122.4 \% \pm 1.3, p \leq 0.001)$ compared with the solvent control (Fig. 2A) (Refolo et al., 2000; Fassbender et al., 2001; Refolo et al., 2001; Ghribi et al., 2006; Xiong et al., 2008). Stigmasterol strongly reduced $A \beta$ levels $(62.00 \% \pm 3.9$, $p=0.0005)$ (Fig. $2 A$ ), whereas $\beta$-sitosterol significantly increased $\mathrm{A} \beta$ secretion $(115.2 \% \pm 2.2, p \leq 0.001)$. For campesterol and brassicasterol $\mathrm{A} \beta$ levels were only slightly elevated compared with solvent control. The determination of $\mathrm{A} \beta 40$ and $\mathrm{A} \beta 42$ peptides using ELISA technique revealed that both $\mathrm{A} \beta$ species were significantly reduced in presence of stigmasterol: $\mathrm{A} \beta 40$ peptides were decreased to $58 \%(58.4 \% \pm 6.8, p=0.0102)$, A $\beta 42$ peptides to $66 \%(65.9 \% \pm 1.9, p=0.049)$ compared with control cells (Fig. $2 B)$.

To exclude that the observed changes in $\mathrm{A} \beta$ secretion in presence of plant sterols are caused by general alterations in protein secretion, we transfected SH-SY5Y wild-type (wt) cells with secretory alkaline phosphatase (SEAP). SEAP secretion was not significantly changed in presence of plant sterols (Fig. 2C). In addition the sterols were significantly taken up by the cells and the uptake was not significantly altered between single plant sterols (uptake $=4.1 \mu \mathrm{g} \pm 0.4 \mu \mathrm{g}$ plant sterol/cholesterol per milligrams protein). Lactate-dehydrogenase-assay ( $\mathrm{LDH}$ ) analysis revealed no signs for elevated cytotoxicity or reduced membrane integrity in presence of sterols compared with solvent control (Fig. 2D).

\section{Cholesterol elevates $\mathrm{A} \beta$ generation by increasing gene expression of $\beta$ - and $\gamma$-secretase and by directly affecting $\boldsymbol{\beta}$ - and $\boldsymbol{\gamma}$-secretase enzymatic activity}

To evaluate whether the observed changes in $\mathrm{A} \beta$ secretion are caused by alterations in $\beta$ - and/or $\gamma$-secretase processing of APP, we systematically investigated the effect of cholesterol and plant sterols on $\beta$ - and $\gamma$-secretase activity, BACE1 and PS1 protein level and gene expression of BACE1 and the components of the $\gamma$-secretase complex. The $\beta$ - and $\gamma$-secretase activities were determined in purified membranes of SH-SY5Y wt cells or mouse brains in presence of sterols and a specific fluorogenic peptide. The use of a cell-free assay using purified membranes, allows identifying the direct influence of sterols on secretase-activities independent of alterations in gene expression and protein level. The specificity of the assay was determined by using specific inhibitors (Fig. 3C,D).

In agreement with increased A $\beta$ levels in APP695-expressing SH-SY5Y cells, cholesterol significantly increased $\beta$-secretase activity in purified membranes of SH-SY5Y wt cells $(119.9 \% \pm 1.4$, $p \leq 0.001)$ and mouse brains $(116.2 \% \pm 0.6, p \leq 0.001)$ compared with the solvent control (Fig. $3 A$ ), indicating a direct effect of cholesterol on $\beta$-secretase enzymatic activity. Elevated $\beta$-secretase activity in presence of cholesterol has been already recently described (Ghribi et al., 2006; Xiong et al., 2008; Liu et al., 2009), validating the results obtained with the $\beta$-secretase assay used in this study. Beside the direct effect of cholesterol on $\beta$-secretase activity, RT-PCR analysis of SH-SY5Y wt cells incubated with cholesterol showed increased gene expression of BACE1 $(154.9 \% \pm 10.9, p=0.002)$ (Fig. 3A). To analyze whether the BACE1 protein level is also changed in presence of cholesterol, we performed WB analysis of BACE1. In accordance with the changed BACE1 expression, BACE1 protein level was also significantly increased in SH-SY5Y wt cells exposed to cholesterol $(110.5 \% \pm 2.5, p=0.022)$ (Fig. $3 A$ ). These findings are in line with the results obtained by Ghribi et al. describing increased BACE 1 protein level in rabbits fed with $1 \%$ cholesterol for 7 months (Ghribi et al., 2006).

As the generation of $\mathrm{A} \beta$ depends on the successive action of $\beta$ and $\gamma$-secretase activity, we next determined the direct effect of cholesterol on $\gamma$-secretase activity in purified membranes of $\mathrm{SH}$ SY5Y wt cells and mouse brains. Similarly to the direct effect of cholesterol on $\beta$-secretase activity, cholesterol directly increased $\gamma$-secretase activity in purified membranes of SH-SY5Y wt cells $(125.9 \% \pm 2.2, p \leq 0.001)$ and mouse brains $(118.4 \% \pm 1.0, p \leq$ 0.001 ) (Fig. $3 B$ ), according to previous studies (Xiong et al., 2008). In addition, cholesterol significantly increased gene expression of all $\gamma$-secretase components, PS1, PS2, APH1A, APH1B, PEN2 and NCSTN, attended by a significant increase in the PS1 protein level $(117.1 \% \pm 1.7, p \leq 0.001)$ (Fig. $3 B)$.

These results indicate that cholesterol increases $\mathrm{A} \beta$ generation by directly affecting $\beta$ - and $\gamma$-secretase activity and by increasing the expression of BACE1 and the $\gamma$-secretase complex.

\section{$\boldsymbol{\beta}$-Sitosterol increases $\mathrm{A} \boldsymbol{\beta}$ generation by increasing gene expression of $\beta$-secretase, but not of the $\gamma$-secretase complex, and by directly elevating $\beta$ - and $\gamma$-secretase enzymatic activity}

Among the plant sterols analyzed, $\beta$-sitosterol showed the strongest increase in $A \beta$ secretion. However, the increase in $A \beta$ generation found for $\beta$-sitosterol was lower compared with cholesterol. Interestingly we found for $\beta$-sitosterol a nearly identical increase in $\beta$-secretase activity in purified membranes of SH-SY5Y wt cells ( $\beta$-sitosterol: $119.1 \% \pm 5.0, p=0.002$ ) (Fig. $4 A$ ) as shown for cholesterol (cholesterol: $119.9 \% \pm 1.4, p \leq$ 0.001 ). Also in purified membranes of mouse brains, $\beta$-sitosterol significantly elevated $\beta$-secretase activity $(109.8 \% \pm 1.1, p \leq$ 0.001 ) (Fig. 4A), however the observed increase was not as strong as found with SH-SY5Y membranes. RT-PCR analysis of SH- 
A

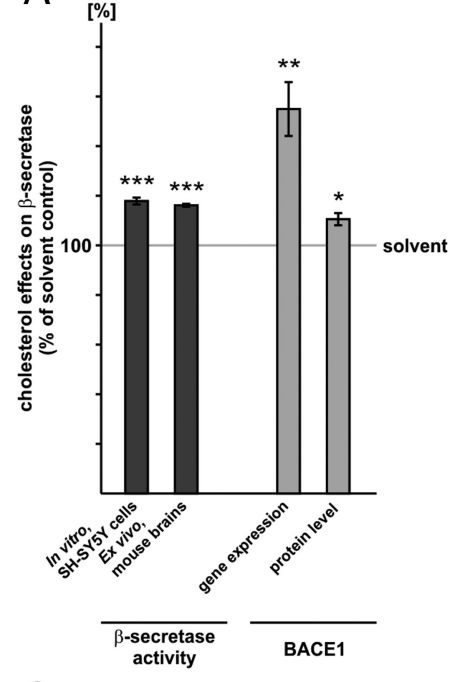

C

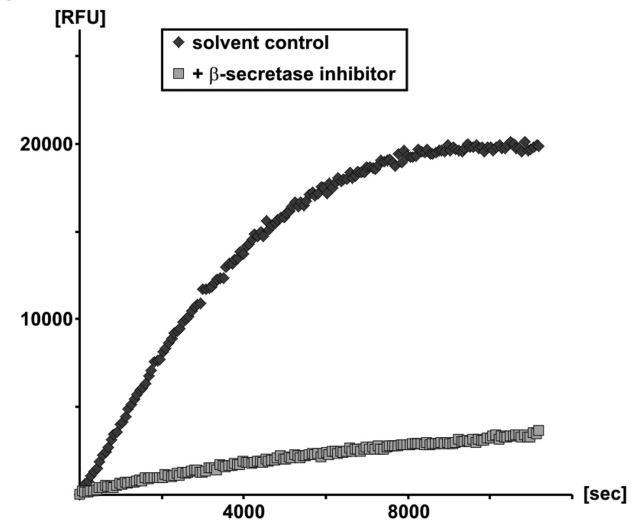

B

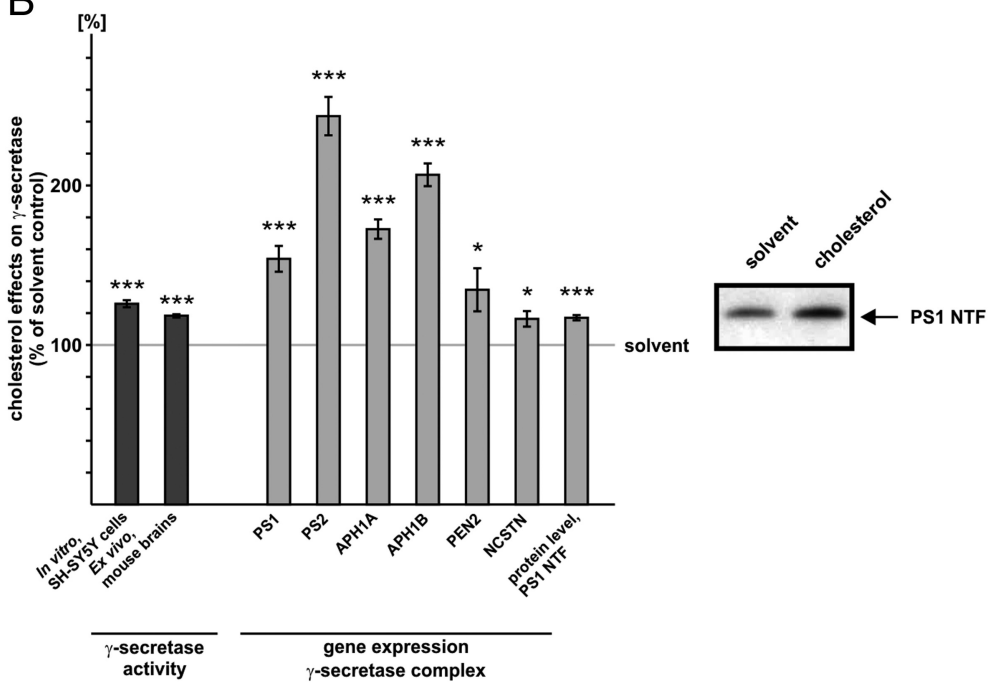

$\mathrm{D}$

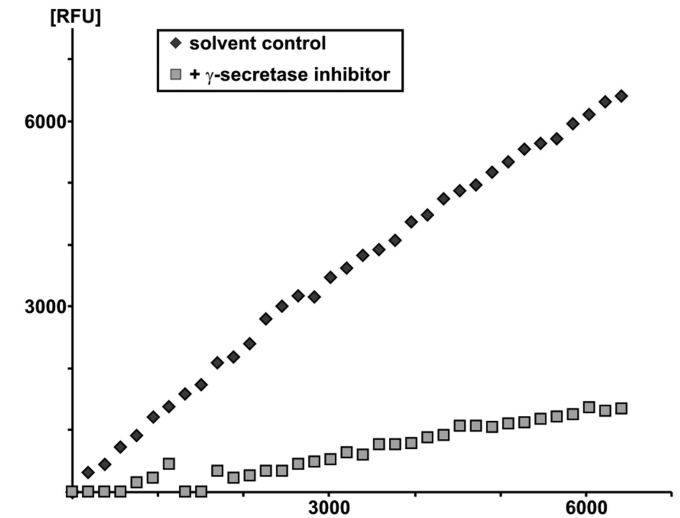

Figure 3. Effect of cholesterol on amyloidogenic $\beta$ - and $\gamma$-secretase cleavage. $A$, Effect of cholesterol on $\beta$-secretase BACE1. Dark-gray bars, Influence of cholesterol on $\beta$-secretase activity in purified membranes of human SH-SY5Y wt cells and ex vivo in purified membranes of mouse brains. Purified membranes were incubated with cholesterol (50nMol/mg protein) or solvent control. The $\beta$-secretase activity was determined by a fluorometric assay. Light-gray bars, Influence of cholesterol on gene expression and protein level of BACE1. SH-SY5Y wt cells were incubated with cholesterol $(10 \mu \mathrm{m})$ or solvent control; total RNA was prepared and mRNA level of BACE1 was determined via RT-PCR. For the determination of BACE1 protein level, cell lysates were prepared, protein level adjusted, and equal volumes of cell lysates loaded and separated on $10-20 \%$ Tris-Tricine gels. WB analysis was performed with antibody B0806. A representative WB is shown. $\boldsymbol{B}$, Influence of cholesterol on $\gamma$-secretase. Dark-gray bars, Influence of cholesterol on $\gamma$-secretase activity in purified membranes of human SH-SY5Y wt cells and ex vivo in purified membranes of mouse brains. Purified membranes were incubated with cholesterol ( $50 \mathrm{nMol} / \mathrm{mg}$ protein) or solvent control and $\gamma$-secretase activity was determined by a fluorometric assay. Light-gray bars, Influence of cholesterol on gene expression of the $\gamma$-secretase components and on the protein level of the PS1 N-terminal fragment (PS1 NTF). SH-SY5Y wt cells were incubated with cholesterol (10 $\mu \mathrm{m}$ ) or solvent control; total RNA was prepared and mRNA levels were determined via RT-PCR for PS1, PS2, APH1A, APH1B, PEN2, and NCSTN. For the analysis of the PS1 protein level, cell lysates were prepared, protein level adjusted, and equal volumes of cell lysates loaded and separated on 10-20\% Tris-Tricine gels. WB analysis was performed with antibody sc7860. A representative WB is shown. $A, B$, Illustration and statistical significance as described for Figure $2 ; n \geq 4$. C, Determination of specificity of the $\beta$-secretase assay. The assay was performed as described using $\beta$-secretase inhibitor II (Calbiochem). D, Determination of specificity of the $\gamma$-secretase assay. The assay was performed as described using $\gamma$-secretase-inhibitor X (Calbiochem).

SY5Y wt cells exposed to $\beta$-sitosterol also revealed increased gene transcription of BACE1 $(121.7 \% \pm 3.3, p \leq 0.001)$, attended by an increase in BACE1 protein level $(108.5 \% \pm 2.6, p=0.034)$ (Fig. 4A).

Similarly to the effect of $\beta$-sitosterol on $\beta$-secretase enzymatic activity, $\beta$-sitosterol also showed a nearly identical potency to increase $\gamma$-secretase activity directly as found for cholesterol using either purified membranes of SH-SY5Y wt cells $(123.3 \% \pm$ $2.4, p \leq 0.001)$ or of mouse brains $(115.9 \% \pm 2.5, p \leq 0.001)$ (Fig. 4B). However, in contrast to cholesterol, $\beta$-sitosterol showed no significant effect on the gene expression of the $\gamma$-secretase complex and as a consequence no effect on the PS1 protein level $(100.5 \% \pm 2.4, p=0.881)$ (Fig. $4 B$ ). Since $\beta$-sitosterol shows no additional effect on the gene expression and protein level of the $\gamma$-secretase complex compared with cholesterol, this should result in lower secreted $\mathrm{A} \beta$ levels compared with cholesterol which was indeed found for $\beta$-sitosterol.

\section{Brassicasterol slightly increases $\mathrm{A} \beta$ generation by directly} affecting $\boldsymbol{\beta}$ - and $\boldsymbol{\gamma}$-secretase activity

For brassicasterol we found only slightly elevated secreted $\mathrm{A} \beta$ levels using APP695-expressing SH-SY5Y cells. The analysis of the $\beta$-secretase cleavage in presence of brassicasterol revealed slightly, however significantly increased $\beta$-secretase enzymatic activity. Brassicasterol directly increased $\beta$-secretase activity in purified membranes of SH-SY5Y wt cells $(108.5 \% \pm 1.9, p=$ $0.0013)$ and mouse brains $(106.6 \% \pm 1.7, p=0.018)$ (Fig. $5 A)$. Gene expression and protein level of BACE1 remained unaffected (Fig. 5A). Similar to the direct effect of brassicasterol on $\beta$-secretase activity, $\gamma$-secretase activity was also slightly, however again significantly elevated in purified membranes of SH-SY5Y wt cells $(108.2 \% \pm 1.0, p \leq 0.001)$ and mouse brains $(111.4 \% \pm$ $1.6 \%, p=0.005$ ) (Fig. $5 B$ ). Significantly altered gene expression was only found for the $\gamma$-secretase components PS2 and APH1B, but not for the homologues PS1 and APH1A, PEN2 and NCSTN 

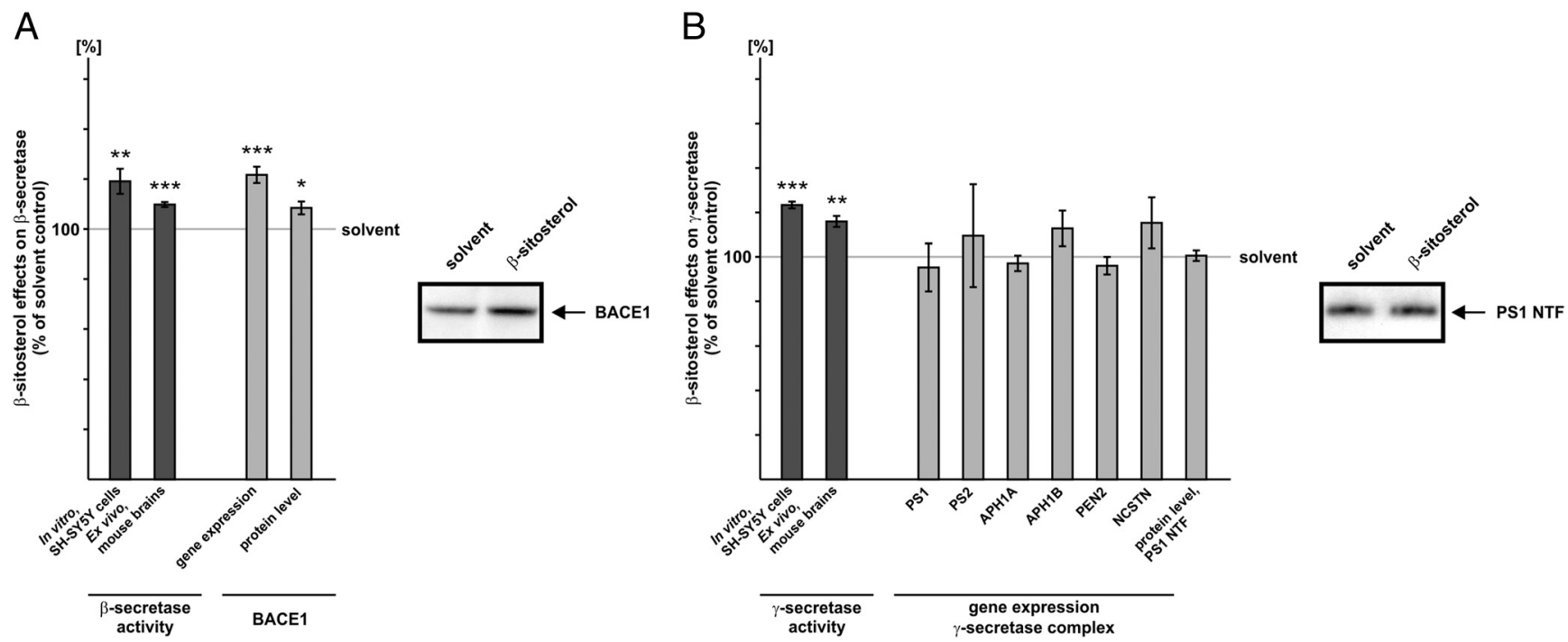

Figure 4. Influence of $\beta$-sitosterol on $\beta$ - and $\gamma$-secretase. $A$, Influence of $\beta$-sitosterol on $\beta$-secretase activity, gene expression, and protein level of BACE1. $\boldsymbol{B}$, Influence of $\beta$-sitosterol on $\gamma$-secretase activity, gene expression of the $\gamma$-secretase complex, and PS1 protein level. $\boldsymbol{A}, \boldsymbol{B}$, Sterol concentration used and analysis of secretase activities, gene expression, and protein level as described for Figure 3. Illustration and statistical significance as described for Figure $2 ; n \geq 6$.
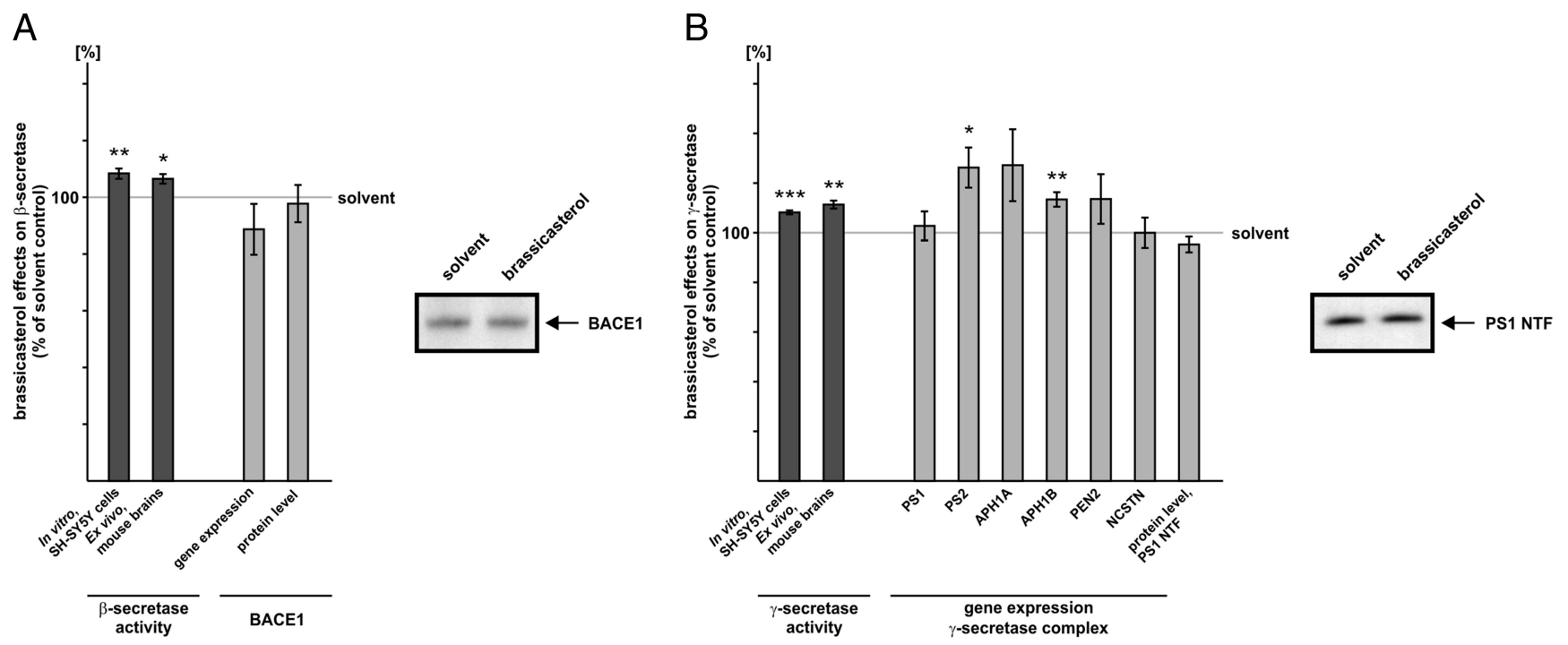

Figure 5. Influence of brassicasterol on $\beta$ - and $\gamma$-secretase. $\boldsymbol{A}$, Effect of brassicasterol on $\beta$-secretase activity, gene expression, and protein level of BACE1. $\boldsymbol{B}$, Influence of brassicasterol on $\gamma$-secretase activity, gene expression of the $\gamma$-secretase complex, and PS1 protein level. $A, B$, Sterol concentration used and analysis of secretase activities, gene expression, and protein level as described for Figure 3. Illustration and statistical significance as described for Figure $2 ; n \geq 6$.

(Fig. 5B). Protein level of PS1 was also unchanged in presence of brassicasterol (Fig. 5B).

\section{Campesterol slightly increases $\mathrm{A} \beta$ secretion by directly affecting $\gamma$-secretase activity}

Beside brassicasterol, campesterol only marginally affected A $\beta$ generation. Analyzing $\beta$ - and $\gamma$-secretase activity, gene expression and protein level of BACE1 and the $\gamma$-secretase complex, we found that the slight increase in $\mathrm{A} \beta$ secretion obtained with APP695-expressing SH-SY5Y cells in presence of campesterol is mainly attributed to increased $\gamma$-secretase activity. The $\beta$-secretase activity was only marginally, but significantly elevated in purified membranes of mouse brains $(104.8 \% \pm 1.4, p=$ 0.049 ), whereas we found no direct effect of campesterol in SH-SY5Y wt membranes (Fig. 6A). In line with the unaffected gene expression of BACE1, the protein level of BACE1 was un- changed (Fig. 6A). However, campesterol significantly increased $\gamma$-secretase activity in purified membranes of SH-SY5Y wt cells $(115.5 \% \pm 3.0, p \leq 0.001)$ and mouse brains $(106.9 \% \pm 1.3, p=$ 0.046) (Fig. 6B). Gene expression of all components of the $\gamma$-secretase complex remained unaffected in presence of campesterol, reflected by unchanged PS1 protein level (Fig. 6B).

\section{Pleiotropic mechanisms are involved in reducing $\mathrm{A} \beta$} secretion in presence of stigmasterol

Stigmasterol directly reduces $\beta$-secretase activity and decreases gene expression of the $\gamma$-secretase complex

Stigmasterol, the plant sterol having the strongest structurally differences compared with cholesterol, was found to be the only sterol to reduce $\mathrm{A} \beta$ generation. The analysis of the $\beta$-secretase activity in purified membranes in presence of stigmasterol revealed slightly however significantly reduced $\beta$-secretase enzy- 

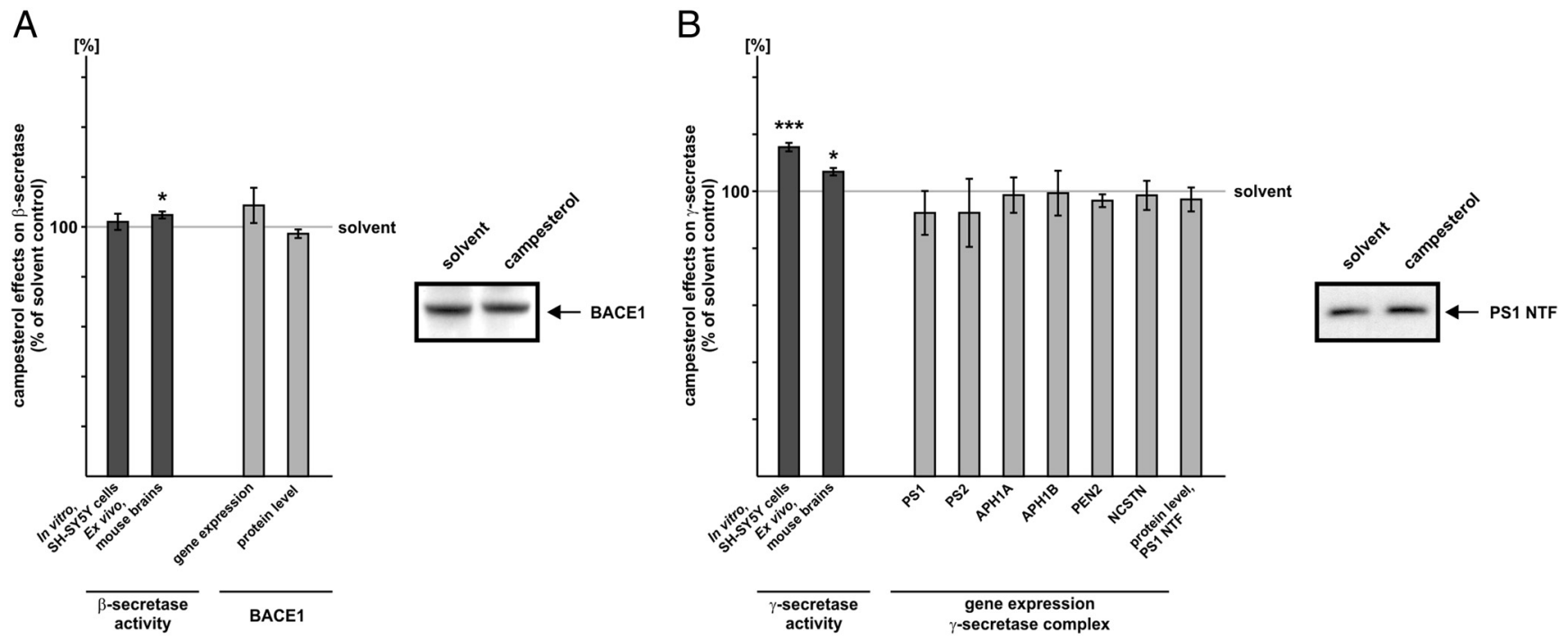

Figure 6. Influence of campesterol on $\beta$ - and $\gamma$-secretase. $\boldsymbol{A}$, Effect of campesterol on $\beta$-secretase activity, gene expression, and protein level of BACE1. $\boldsymbol{B}$, Influence of campesterol on $\gamma$-secretase activity, gene expression of the $\gamma$-secretase complex, and PS1 protein level. $\boldsymbol{A}, \boldsymbol{B}$, Sterol concentration used and analysis of secretase activities, gene expression, and protein level as described for Figure 3. Illustration and statistical significance as described for Figure 2; $n \geq 5$.

matic activity. For SH-SY5Y wt membranes we found $\beta$-secretase activity to be decreased to $90 \%(90.3 \% \pm 2.5, p=0.002)$, for mouse brain membranes to $85 \%(84.9 \% \pm 1.5, p \leq 0.001)$ (Fig. $7 A$ ). In contrast to the direct effect of stigmasterol on $\beta$-secretase activity, no significant changes on gene expression and protein level of BACE1 were obtained (Fig. 7A). Similarly, stigmasterol does not directly affect $\gamma$-secretase activity as we observed no alterations in $\gamma$-secretase enzymatic activity in purified membranes of SH-SY5Y wt cells and mouse brains (Fig. 7B). Instead, in presence of stigmasterol mRNA levels of all $\gamma$-secretase components were significantly reduced to $74 \%-89 \%$, attended by a significant decrease in the PS1 protein level $(85.3 \% \pm 1.2, p \leq$ 0.001 ) (Fig. 7B). To evaluate whether the observed reduced gene expression of the $\gamma$-secretase complex results in decreased $A \beta$ levels, we analyzed A $\beta$ secretion in SH-SY5Y cells stably transfected with the truncated APP construct SPC99. SPC99 represents the C-terminal fragment of $\beta$-secretase cleaved APP, which allows studying the influence of sterols on $\gamma$-secretase cleavage, independent of $\beta$-secretase activity. Indeed, $A \beta$ generation was also significantly reduced to $78 \%$ in stigmasterol-treated $\mathrm{SH}$ SY5Y cells stably transfected with the truncated APP construct SPC99 $(78.5 \% \pm 3.6, p=0.009)$ (Fig. $7 B)$.

\section{Stigmasterol decreases $\beta$-secretase cleavage by reducing BACE1} internalization to the endosomal compartments

As we observed only a minor effect of stigmasterol on directly decreasing $\beta$-secretase activity we asked whether $\beta$-secretase cleavage of APP is affected by additional mechanisms in presence of stigmasterol. Since the endosomal compartments have been found to be the major cellular site of BACE1 activity (Huse et al., 2000), we analyzed whether stigmasterol interferes with BACE1 internalization from the plasma membrane to the endosomes. Biotinylation of cell surface localized proteins revealed a strong increase in biotinylated BACE1 in presence of stigmasterol (137.4\% $\pm 8.0, p=0.016)$ compared with control cells, indicating that BACE1 accumulates at the plasma membrane (Fig. $7 C$ ). Levels of biotinylated APP were unchanged (Fig. 7C), suggesting that the observed effect is specific for BACE1. Similarly, protein level of the EEA1 was not affected in cell-lysates of stigmasteroltreated SH-SY5Y wt cells compared with control cells. BACE1 accumulation at the plasma membrane might be caused by reduced internalization of BACE1 to the endosomal compartments. To analyze whether stigmasterol might additionally decrease $\beta$-secretase cleavage of APP by diminishing BACE1 internalization, we isolated endosomes by density centrifugation. Cell fractionation followed by gel electrophoresis and WB analysis of the collected fractions resulted in three fractions positive for the EEA1 (Fig. 7D). EEA1-positive fractions were pooled and analyzed for $\beta$-secretase activity, the $\mathrm{C}$-terminal fragment generated by $\beta$-secretase processing of APP $(\beta-\mathrm{CTF})$ and for BACE1 protein level. Indeed, the protein level of BACE1 was significantly reduced in EEA1-positive fractions in presence of stigmasterol $(86.9 \% \pm 1.9, p \leq 0.001)$, accompanied by a similar decrease in $\beta$-secretase activity $(85.8 \pm 1.8, p \leq 0.001)$ and the product of $\beta$-secretase-mediated APP cleavage, $\beta$-CTF $(90.0 \% \pm 1.5, p=$ 0.003) (Fig. 7D).Together, these results indicate that stigmasterol also decreases $\beta$-secretase cleavage of APP and thus A $\beta$ generation, by diminishing BACE1 internalization from the cell surface to the endosomal compartments.

\section{Stigmasterol decreases $\gamma$-secretase activity by affecting cholesterol} distribution in lipid rafts

Cholesterol within mammalian cells as well as plant sterols within plant cell membranes have been shown to be organized in specialized microdomains of the plasma membrane, also called lipid rafts (Simons and Ikonen, 1997; Mongrand et al., 2010). Lipid rafts are involved in $\beta$ - and $\gamma$-secretase cleavage of APP (Ehehalt et al., 2003; Vetrivel and Thinakaran, 2010) and in line with our results, it has been shown that alterations in the cholesterol level influence A $\beta$ generation (Refolo et al., 2000; Fassbender et al., 2001; Wahrle et al., 2002; Ghribi et al., 2006). As plant sterols, compared with cholesterol, have a similar sterol backbone, we analyzed whether stigmasterol affects cholesterol distribution and thus $\gamma$-secretase activity in lipid raft membrane microdomains. To address this question, SH-SY5Y wt cells were incubated with stigmasterol or the solvent control and raft and nonraft membrane microdomains were obtained by sucrose buoyant density centrifugation. To identify raft and nonraft membrane microdomains, collected gradient fractions were immunoblotted against raft marker protein flotillin or cadherin for 
A

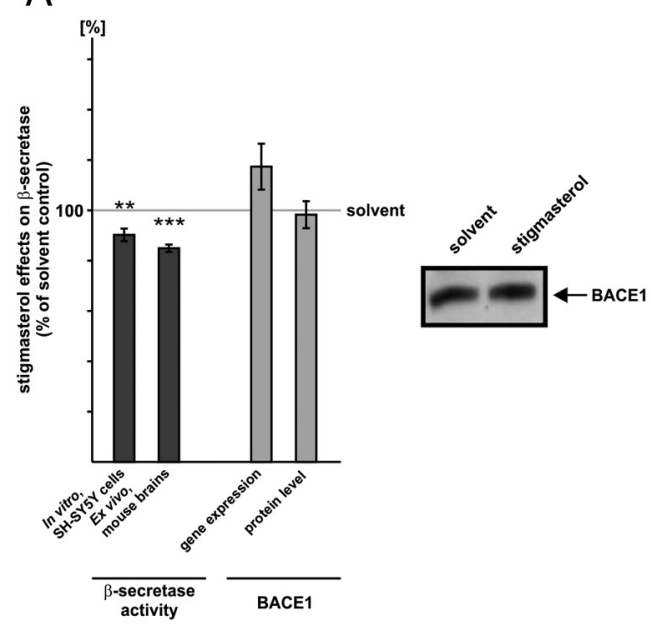

C

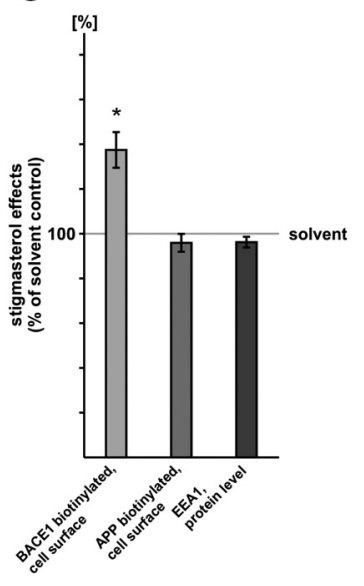

B

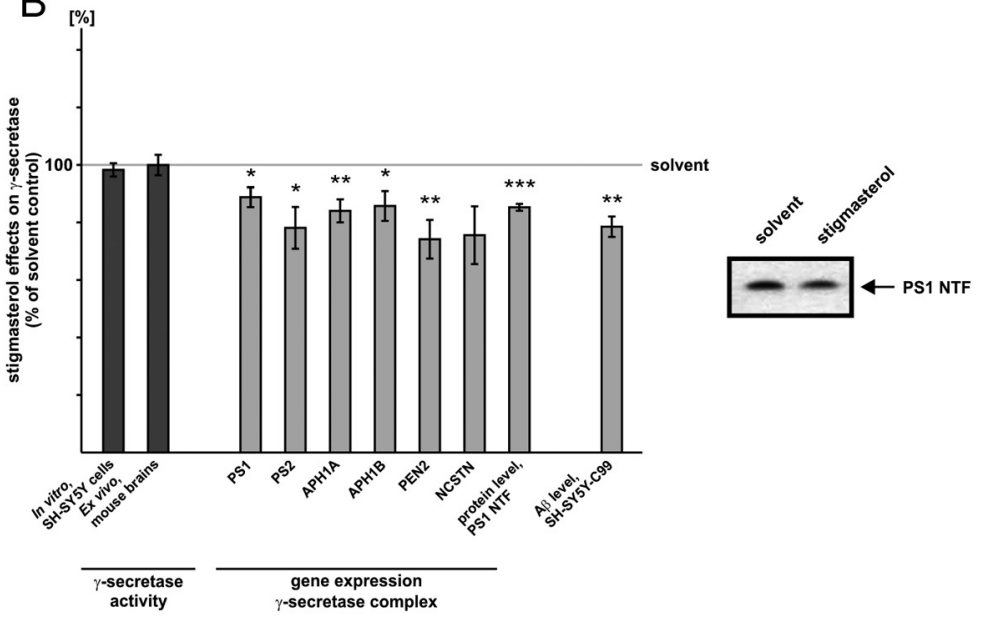

D

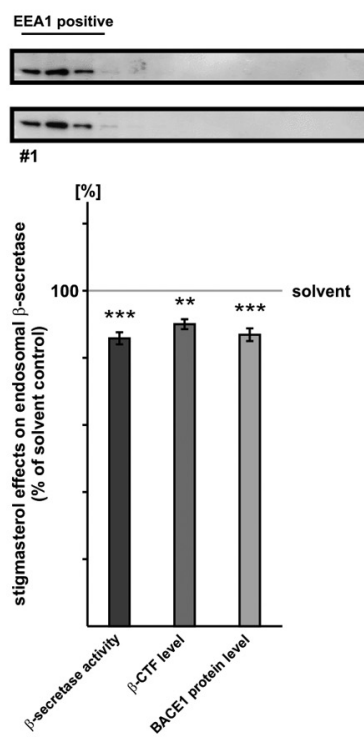

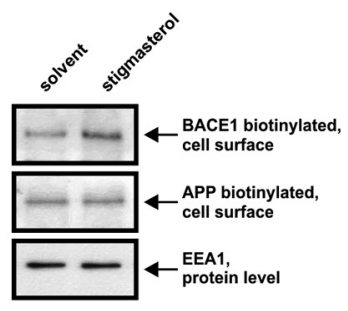

$E$

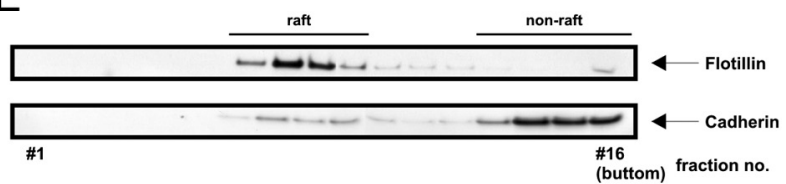

$\mathrm{F}$
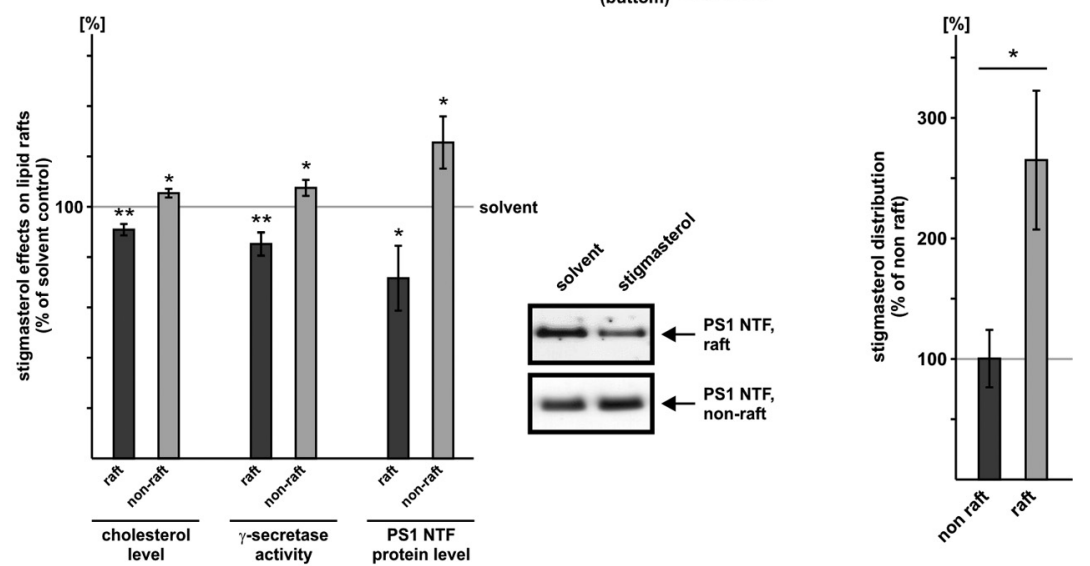

Figure 7. Stigmasterol reduces $A \beta$ generation via pleiotropic mechanisms. $A$, Effect of stigmasterol on $\beta$-secretase BACE1. Dark-gray bars, Stigmasterol reduces $\beta$-secretase activity directly in purified membranes of SH-SY5Y wt cells and of mouse brains. Light-gray bars, Stigmasterol has no effect on BACE1 expression. Sterol concentration used and analysis of secretase activities and BACE1 expression as described for Figure 3A.B, Influence of stigmasterol on $\gamma$-secretase. Dark-gray bars, Stigmasterol does not affect $\gamma$-secretase activity directly in purified membranes of SH-SY5Y wt cells and of mouse brains. Light-gray bars, left, Stigmasterol significantly decreases gene expression of all $\gamma$-secretase components, PS1, PS2, APH1A, APH1B, PEN2, and NCSTN, resulting (Figure legend continues.) 
the determination of gradient fractions representing nonraft membrane microdomains (Fig. 7E). The analysis of the cholesterol content in the collected fractions revealed that the cholesterol level was significantly reduced in raft-positive fractions when cells were incubated with stigmasterol (cholesterol/rafts: $90.9 \% \pm 2.3, p=0.007$ ) (Fig. 7E). As a consequence of the reduced cholesterol level in lipid rafts, $\gamma$-secretase activity should be decreased since we have shown that cholesterol directly activates $\gamma$-secretase activity. Indeed, $\gamma$-secretase activity was also significantly reduced in raft membrane microdomains $(\gamma$-sec) rafts: $85.2 \% \pm 4.6, p=0.009$ ), whereas activity of $\gamma$-secretase was slightly, however, significantly increased in nonraft gradient fractions ( $\gamma$-sec/nonrafts: $107.5 \% \pm 3.2, p=0.039)$ (Fig. $7 E)$. The increase in $\gamma$-secretase activity in nonraft microdomains might be caused by the elevated cholesterol level in nonraft gradient fractions in stigmasterol-incubated cells (cholesterol/nonrafts: $105.4 \% \pm 1.7, p=0.021$ ) (Fig. $7 E$ ). Notably, stigmasterol distribution to lipid raft-positive fractions were 2.56 fold increased compared with stigmasterol content in nonraft membrane microdomains (Fig. $7 F$ ). The stigmasterol-induced shift of cholesterol and $\gamma$-secretase activity from rafts to nonraft membrane microdomains was attended by a shift of PS1 protein from raft to nonraft gradient fractions (PS1/rafts: 71.6\% $\pm 12.9, p=0.033$; PS1/nonrafts: $125.5 \% \pm 10.4, p=0.026$ (Fig. $7 E$ ), also contributing to a reduced $\gamma$-secretase cleavage in lipid rafts. These data indicate that stigmasterol reduces $\mathrm{A} \beta$ generation by incorporating in lipid raft membrane microdomains, thus displacing cholesterol and PS1 out of lipid rafts and therefore reducing $\gamma$-secretase cleavage in lipid rafts.

\footnotetext{
$\leftarrow$

(Figure legend continued.) in a reduced PS1 protein level. Sterol concentration, analysis of gene transcription, and PS1 protein level as described for Figure 3B. Light gray bar, right, Influence of stigmasterol on secreted A $\beta$ levels in SH-SY5Y cells stably expressing SPC99. SPC99-expressing SH-SY5Y cells were incubated with $10 \mu$ m stigmasterol or solvent control. Secreted $A \beta$ levels were immunoprecipitated with antibody W02, and WB analysis was performed with antibody W02. C, Biotinylation of cell surface localized proteins in presence of stigmasterol. SH-SY5Y wt cells were incubated with $10 \mu \mathrm{m}$ stigmasterol or solvent control, scraped off, and biotinylation was performed as described in Material and Methods. Biotinylated proteins were immunoprecipitated using streptavidin agarose. WB analysis of biotinylated APP was performed with antibody W02, WB analysis of biotinylated BACE1 with antibody B0806. Cell-lysates were analyzed for total protein level of EEA1 of stigmasterol-treated cells or control cells. WB analysis was performed with antibody ab2900. D, Stigmasterol reduces BACE1 internalization. Stigmasterol-treated cells $(10 \mu \mathrm{m})$ and control cells were fractionated using OptiPrep density gradient centrifugation. Collected fractions were loaded and separated on $10-20 \%$ Tris-Tricine gels. WB analysis was performed with anti-EEA1 antibody. EEA1-positive fractions were pooled and analyzed for BACE1 protein level as described for Figure $3 A . \beta$-CTF was detected using antibody W02 for WB analysis. EEA1-positive fractions were also analyzed for $\beta$-secretase activity. E, Stigmasterol affects cholesterol level, $\gamma$-secretase activity, and PS1 protein level in lipid rafts. Stigmasterol-treated cells $(10 \mu \mathrm{M})$ and control cells were subjected to buoyant sucrose density centrifugation and 16 fractions were collected. Fractions were loaded, separated on 10-20\% Tris-Tricine gels and subjected to WB analysis. For the detection of raft-positive gradient fractions, the antibody anti-flotillin 610821 was used, for the detection of nonraft fractions the antibody anti-cadherin ab6528. Determination of cholesterol level, $\gamma$-secretase activity, and PS1 protein level in raft and nonraft membrane microdomains. For the determination of the cholesterol content, SH-SY5Y wt cells were pulsed with ${ }^{14} \mathrm{C}$-cholesterol and afterward incubated with $10 \mu \mathrm{m}$ stigmasterol as described in Materials and Methods. Cholesterol levels were determined by liquid scintillation counting in a Tri-Carb2800TR, $\gamma$-secretase activity via the fluorescent $\gamma$-secretase assay as described in Material and Methods. PS1 protein level was detected using antibody sc7860. A-E, Representative WBs for protein analysis experiments are shown. Illustration and statistical significance as described for Figure $2 ; n \geq 4$. F, Stigmasterol distribution to raft and nonraft microdomains. Pooled raft/nonraft samples were subjected to derivatization and mass spectrometry as described in Materials and Methods to determine stigmasterol content in raft and nonraft membrane microdomains.
}

\section{Stigmasterol-enriched diets decrease amyloidogenic APP processing in vivo}

To examine whether stigmasterol, the only plant sterol showing anti-amyloidogenic properties, might also be beneficial in vivo, mice were fed with two stigmasterol-enriched diets, containing different amounts of stigmasterol. Whereas brain $\beta$-secretase activity from mice fed with a diet containing $0.19 \%$ stigmasterol $(+)$ was not significantly reduced $(\beta-$ sec/ $+: 90.5 \% \pm 4.3$, n.s.), $\beta$-secretase activity was significantly decreased when the diet contained $0.39 \%$ of stigmasterol $(++)(\beta$-sec/ $++: 79.1 \% \pm 2.1, p \leq 0.001)$ compared with mice fed with normal chow (Fig. $8 A$ ). For mouse blood cells we found significantly decreased $\beta$-secretase activity for both stigmasterol-enriched diets $(\beta$-sec/+: 91.0\% \pm 0.6, $p=$ $0.0013 ; \beta$-sec/ $++: 85.9 \% \pm 2.9, p=0.003$ ) (Fig. $8 A$ ). The $\gamma$-secretase activity was significantly and dose-dependently decreased in mouse brains obtained from mice fed with the stigmasterol-enriched diets compared with control mice $(\gamma$ sec/ $/: 84.8 \% \pm 3.2, p=0.008 ; \gamma$-sec $/++: 70.8 \% \pm 4.8, p \leq$ 0.001 ) (Fig. 8A). Significantly reduced $\gamma$-secretase activity was also obtained for blood cells of these mice $(\gamma$-sec $/+: 77.5 \% \pm$ $2.8, p=0.003 ; \gamma$-sec/ $++: 82.3 \% \pm 4.3, p=0.021)$ (Fig. $8 A$ ).

In accordance to the reduced PS1 protein level and unchanged BACE1 protein level in cells incubated with stigmasterol (Fig. $7 A, B)$, PS1 protein level was also significantly decreased in stigmasterol (++)-fed mice (PS1: 84.1\% $\pm 3.2, p=0.008)$ (Fig. $8 B$ ), and protein level of BACE1 was not significantly changed. As a consequence of reduced $\beta$ - and $\gamma$-secretase activity (Fig. $8 A$ ), soluble $\mathrm{A} \beta$ levels were also decreased in mouse brains fed with a stigmasterol-enriched diet (Fig. $8 C$ ). Similar to the results obtained with cell culture experiments, both $\mathrm{A} \beta$ species were significantly reduced in stigmasterol-fed mice (A $\beta 40: 86.5 \% \pm 2.3, p=$ 0.0018; A $342: 84.2 \% \pm 1.8, p \leq 0.001$ ) (Fig. $8 D$ ). These data indicate that indeed nutritional intake of stigmasterol can reduce the cerebral activity of amyloidogenic enzymes in vivo and thus $\mathrm{A} \beta$ levels in brain.

However, as plant sterols interfere with the intestinal resorption of cholesterol (Ostlund, 2002; Richelle et al., 2004), the observed effect on amyloidogenic processing in stigmasterol-fed mice might be a consequence of altered cholesterol level in the brains of these animals. To evaluate whether the reduced amyloidogenic processing in vivo is caused by stigmasterol itself and not accompanied by reduced cholesterol, we examined stigmasterol and cholesterol level in serum and brain samples of these animals. The analysis of cholesterol and stigmasterol in serum samples of stigmasterol $(+)$ - and $(++)$-fed mice revealed no change in the cholesterol level, whereas stigmasterol was significantly increased compared with serum samples of control animals (Fig. $8 E, F$ ), indicating efficient dietary stigmasterol uptake. In brain samples, cholesterol level was also unchanged, the level of stigmasterol was dose-dependently increased compared with the control diet (Fig. 8G,H), emphasizing that stigmasterol passed the blood-brain-barrier and is the cause for the observed reduced $\beta$ - and $\gamma$-secretase activities.

\section{Discussion}

To evaluate whether dietary intake of plant sterols might be beneficial for the prevention of $\mathrm{AD}$, we analyzed the effect of plant sterols and cholesterol on the molecular mechanisms of APP processing.

We found that stigmasterol was the only plant sterol that significantly decreased $\mathrm{A} \beta$ levels. Compared with stigmasterol, $\beta$-sitosterol and cholesterol significantly increased $\mathrm{A} \beta$ levels, 

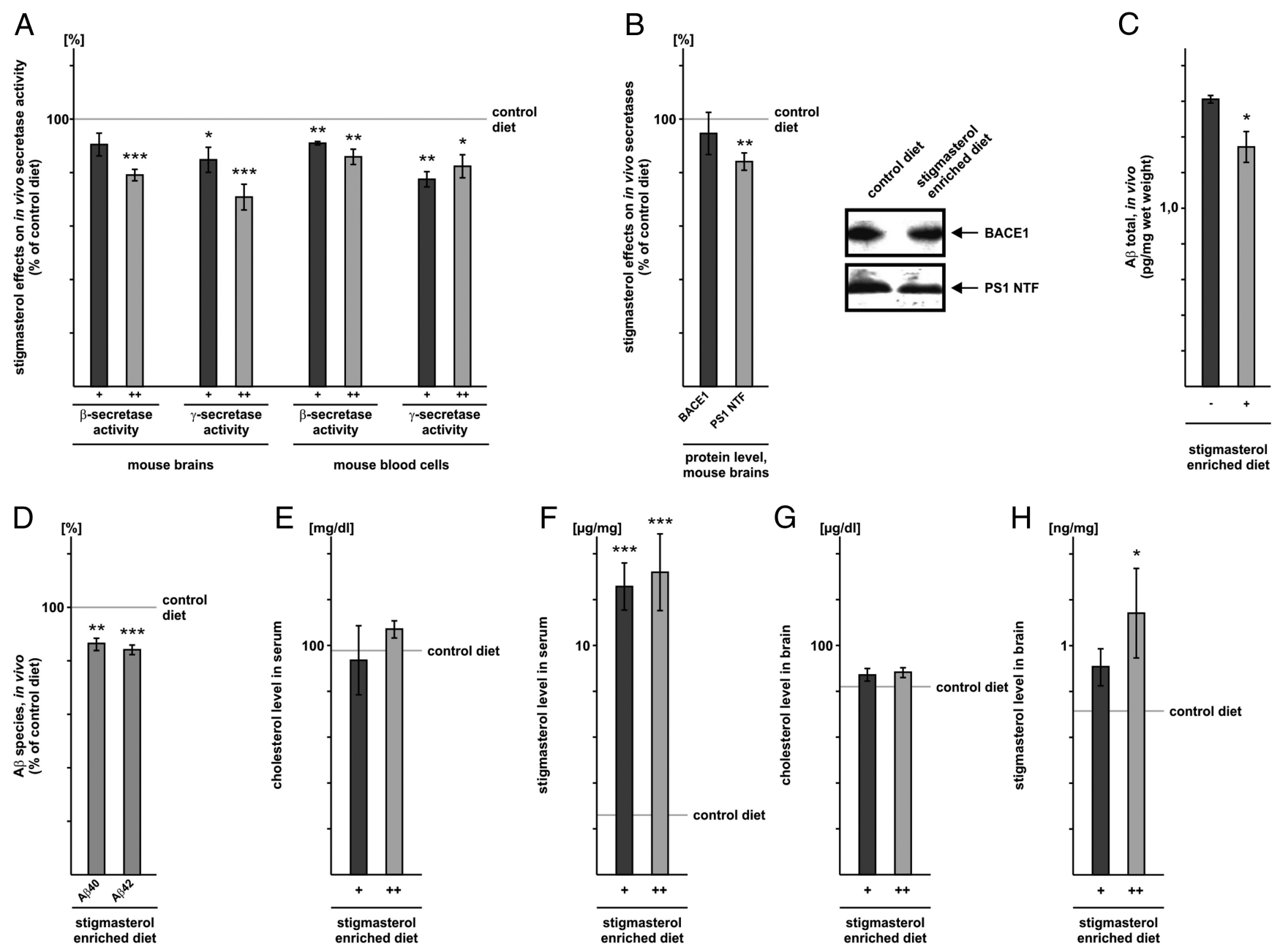

Figure 8. Effect of stigmasterol on proteolytic processing of APP in mice fed with stigmasterol-enriched diets. $A$, Determination of $\beta$ - and $\gamma$-secretase activity in brains and blood cells of mice fed with a diet containing $0.19 \%(+)$ or $0.39 \%(++)$ of stigmasterol. $\boldsymbol{B}$, Protein level BACE1 and PS1 in mice fed with the stigmasterol-enriched diet containing higher amounts (++) of stigmasterol. Brain homogenates were prepared and analyzed by WB using antibody PC529 (anti-BACE1) and sc7860 (anti-PS1). C, Determination of soluble A $\beta$ level (A $\beta 40$ and A $\beta 42$ ) in brains of mice fed with a stigmasterol-enriched diet or the control diet. $\boldsymbol{D}$, Determination of $A \beta 40$ and $A \beta 42$ peptides in brains of mice fed with a stigmasterol-enriched diet or the control diet. $\boldsymbol{A}-\boldsymbol{D}$, Illustration and statistical significance as described for Figure 2 . E, Determination of cholesterol level in serum of stigmasterol-fed mice containing $0.19 \%(+)$ or $0.39 \%(++)$ of stigmasterol. $\boldsymbol{F}$, Determination of stigmasterol level in serum of stigmasterol-fed mice containing $0.19 \%(+)$ or $0.39 \%(++)$ of stigmasterol. G, Determination of cholesterol level in brain of stigmasterol-fed mice containing $0.19 \%$ $(+)$ or $0.39 \%(++)$ of stigmasterol. $\boldsymbol{H}$, Determination of stigmasterol level in brain of stigmasterol-fed mice containing $0.19 \%(+)$ or $0.39 \%(++)$ of stigmasterol. $\boldsymbol{E}, \mathbf{G}$, Cholesterol content was determined by GC-FID. $\boldsymbol{F}, \boldsymbol{H}$, Stigmasterol content was analyzed by a method of GC-MS. All quantified data represent an average of six independent mouse brains/blood cells $(n=6)$.

whereas campesterol and brassicasterol showed minor or no effect on $\mathrm{A} \beta$ secretion. Interestingly, the $\mathrm{A} \beta$-reducing plant sterol stigmasterol is structurally the most distinctive from cholesterol, having an additional double-bond at C22-C23 and an ethylgroup at $\mathrm{C} 24$. The analysis of the molecular mechanisms revealed that stigmasterol directly inhibited $\beta$-secretase activity and further reduced $\beta$-secretase cleavage of APP by decreasing BACE1 internalization from the plasma membrane to the endosomal compartments, known to have an optimal acidic $\mathrm{pH}$ for BACE1 cleavage of APP (Vassar et al., 1999; Huse et al., 2000). In addition, the stigmasterol-induced reduction of secreted $\mathrm{A} \beta$ levels, $\mathrm{A} \beta 40$ and $\mathrm{A} \beta 42$, is caused by reduced gene transcription of all $\gamma$-secretase components, further validated by a decrease in the protein level of PS1, the catalytic active part of the heterotetrameric $\gamma$-secretase (Herreman et al., 2000). Interestingly, we found that stigmasterol can incorporate in lipid raft membrane microdomains of mammalian cells, accompanied by a reduction in the cholesterol content in lipid rafts. The decrease in the cholesterol content in lipid raft membrane microdomains to $90 \%$ in presence of stigmasterol might be rather small, however, as cho- lesterol has been shown to alter $\mathrm{A} \beta$ production via multiple mechanisms, a $10 \%$ decreased cholesterol level in lipid rafts might have a more pronounced effect on $\mathrm{A} \beta$ generation.

First, we and others could show that cholesterol directly activates $\gamma$-secretase activity (Wahrle et al., 2002; Xiong et al., 2008). We found $\gamma$-secretase activity to be reduced in lipid raft membrane microdomains in presence of stigmasterol, which might be a consequence of the reduced cholesterol level. Taken into consideration that in the present study as well as in previous studies cholesterol also directly increased $\beta$-secretase activity (Ghribi et al., 2006; Liu et al., 2009), a reduced level of cholesterol in lipid rafts should further decrease $A \beta$ generation, as $\beta$-secretase BACE1 has been shown to be raft-associated (Riddell et al., 2001; Sakurai et al., 2008).

Second, cholesterol has been shown to increase the accessibility of BACE1 to its substrate APP by relocalization of APP from nonraft membrane microdomains to lipid rafts, already containing BACE1, followed by rapid endocytosis (Marquer et al., 2011). Furthermore, it has been shown that cholesterol depletion decreases endocytosis, which is crucial for BACE1 cleavage of APP 
(Huse et al., 2000). As we found reduced cholesterol level in lipid rafts in presence of stigmasterol, one might speculate that the reduced internalization of BACE1 that we found in presence of stigmasterol might be caused by the reduced cholesterol level in lipid raft membrane microdomains. However, in this context one has to consider that lipid raft-associated proteins are known to be generally internalized through clathrin-independent pathways, whereas cholesterol depletion mainly affects clathrin-dependent endocytosis (Rodal et al., 1999; Subtil et al., 1999). However, recent evidence suggests a link between lipid rafts and clathrinmediated endocytosis as it has been shown that lipid-raft associated proteins can be internalized by clathrin-coated pits (Stoddart et al., 2002; Rollason et al., 2007). Furthermore, cholera and anthrax toxins enter cells through lipid rafts by clathrindependent mechanisms (Abrami et al., 2003; Hansen et al., 2005). Interestingly, in presence of stigmasterol, cholesterol content, $\gamma$-secretase activity, and PS1 protein level was increased in nonraft membrane microdomains. In contrast to the lipid raft-associated amyloidogenic APP processing (Vetrivel and Thinakaran, 2010), nonamyloidogenic processing of APP by $\alpha$-secretases preventing A $\beta$ generation is discussed to take place outside of lipid rafts (Kojro et al., 2001; Parr-Sturgess et al., 2010), suggesting that stigmasterol might shift APP cleavage toward nonamyloidogenic processing. A similar shift of cholesterol and $\gamma$-secretase activity toward nonamyloidogenic processing of APP in nonraft membrane microdomains was recently reported to be induced by the $\omega-3$ fatty acid docosahexaenoic acid (Grimm et al., 2011b), indicating that in general a slight shift of cholesterol from raft to nonraft membrane microdomains might be beneficial to reduce $\mathrm{A} \beta$ generation.

Stigmasterol-induced effects are all between 10\% and 30\% and less pronounced compared with e.g., synthetic secretase inhibitors (Shearman et al., 2000; Probst et al., 2013). However, these obviously minor effects on different cellular processes, including direct modulation of enzymes, gene expression, and subcellular transport processes, result in a $38 \%$ reduced $\mathrm{A} \beta$ generation. Furthermore, it has to be considered that BACE1 and $\gamma$-secretase not only cleave APP. BACE1 substrates include proteins with important neuronal functions, like the $\beta 2$-subunit of the voltage-gated sodium channel $(\mathrm{Nav} \beta 2)$ (Wong et al., 2005) and neuregulin-1 (Willem et al., 2006), suggesting that a strong therapeutic inhibition of BACE1 activity might affect neuronal membrane excitability. It has been reported that BACE activity is increased in sporadic AD (Yang et al., 2003). Some current approaches therefore target this elevated BACE activity to decrease it to a physiological level instead of completely inhibiting BACE activity. In line, the moderate inhibition of BACE activity by stigmasterol could facilitate physiological BACE activity. Similarly, total inhibition of $\gamma$-secretase activity might not be suitable to treat AD. The $\gamma$-secretase is beside APP essential for the proteolysis of many type-I transmembrane proteins, e.g., Notch, ErbB4, CD44, LRP1, and jagged (Parks and Curtis, 2007). Therefore, a slight and combined modulation of $\beta$ - and $\gamma$-secretase activity affecting different cellular processes as observed for stigmasterol might be more suitable.

Beside directly increasing $\beta$ - and $\gamma$-secretase activity, we found that cholesterol significantly elevates gene expression of all $\gamma$-secretase components and of $\beta$-secretase BACE1 attended by an increase of PS1 and BACE1 protein level. Increased BACE1 gene expression was already described in low density lipoprotein receptor (LDLR)-deficient mice fed with a high fat/cholesterol diet for an 8 week period (Thirumangalakudi et al., 2008). In addition, Parsons et al. (2007) reported reduced BACE1 expres- sion in human embryonic kidney cells when cholesterol synthesis was inhibited. In line with our in vitro findings, BACE1 protein level has been shown to be increased in rabbits fed with $1 \%$ cholesterol for 7 months (Ghribi et al., 2006). Cholesterol increases $\mathrm{A} \beta$ generation by directly activating $\beta$ - and $\gamma$-secretase enzyme activity and by elevating gene expression of $\beta$ - and $\gamma$-secretase. For $\beta$-sitosterol we observed a nearly identical increase in $\beta$ - and $\gamma$-secretase activity as obtained for cholesterol, resulting in significantly increased $A \beta$ levels. However, in contrast to cholesterol, $\beta$-sitosterol only elevates gene expression of BACE1 but not of the $\gamma$-secretase components. As $\beta$-sitosterol only elevates gene transcription of BACE1 resulting in increased BACE1 protein level but unchanged protein level of PS1, it is not remarkable that for $\beta$-sitosterol the observed increase in the $A \beta$ level is reduced compared with cholesterol.

Based on these findings, cholesterol is highly amyloidogenic whereas all analyzed plant sterols are not as amyloidogenic as cholesterol to the point of stigmasterol that significantly decreased amyloidogenic processing of APP, suggesting that a diet enriched in plant sterols mainly containing stigmasterol might be beneficial for AD. Indeed, in vivo, $\beta$ - and $\gamma$-secretase activities were also significantly decreased in mice fed with a stigmasterol-enriched diet, accompanied by reduced brain $\mathrm{A} \beta$ levels, $A \beta 40$ and $A \beta 42$. Although phytosterols reduce the intestinal resorption of cholesterol (Richelle et al., 2004), brain cholesterol level of stigmasterol-fed mice were unaffected, whereas brain stigmasterol levels were increased. This is in line with the findings that brain cholesterol homeostasis is widely independent of ingested cholesterol (Vance et al., 2005). The above mentioned reduction of secretase activities in vivo might be attributed to a reduction of cholesterol in brain lipid rafts as we found reduced cholesterol and increased stigmasterol level in rafts after stigmasterol incubation, thus reducing secretase activities in rafts.

The estimated daily dietary intake of naturally occurring phytosterols ranges from 100 to $450 \mathrm{mg}$ (Berger et al., 2004). Among edible oils, maize, wheat germ, and rapeseed oils have been shown to be the richest phytosterol sources (Phillips et al., 2002; Schwartz et al., 2008), however, higher stigmasterol level have been found for soybean oil (up to $82,4 \mathrm{mg} / 100 \mathrm{~g}$ ) (Lechner et al., 1999). Normen et al. (2002) reported a mean phytosterol concentration for cereals of $49 \mathrm{mg} / 100 \mathrm{~g}$; the median content of stigmasterol was $2 \mathrm{mg} / 100 \mathrm{~g}$. A recent study analyzing ingredients used to enrich foods with phytosterols revealed high stigmasterol contents in two ingredients (6.6\% stigmasterol and $17.8 \%$ stigmasterol of total phytosterols) (González-Larena et al., 2011). Compared with the stigmasterol content used for our in vivo studies, $190 \mathrm{mg} / 100 \mathrm{~g}$ and $390 \mathrm{mg} / 100 \mathrm{~g}$, the stigmasterol contents in natural foods are lower. However, it has to be mentioned that mice were fed 6 weeks with the stigmasterolenriched diets, and that this short time period already showed anti-amyloidogenic effects. In humans, the time period of dietary phytosterol intake would be expected to be longer and continuously. Therefore, functional foods might be suitable to achieve higher stigmasterol uptake in the human diet. However, whether the stigmasterol concentrations in functional foods are indeed sufficient to reduce $\mathrm{A} \beta$ generation in humans has still to be elucidated.

\section{Conclusion}

Food products containing plant sterols have been widely used as therapeutic diets or food supplements to lower plasma cholesterol, atherosclerosis risk, and the risk for coronary heart diseases 
(Plat and Mensink, 2001; Ostlund, 2002; Acuff et al., 2007; CalpeBerdiel et al., 2009). However, up to now it has been controversially discussed whether these lipids are indeed protective. It is important to notice that mainly blends containing different phytosterols are used as food supplements and that studies systematically investigating potential differences between these phytosterols in respect to their biological properties and activities are still missing. It was recently shown that plant sterols can pass the blood-brain barrier and accumulate in the brain, underlying the importance of the question whether plant sterols are biologically active compounds in the brain. Their similarity to cholesterol also raises the question what kind of properties phytosterols might have in respect to AD. This issue was addressed by our study, where we investigated the effect of the major plant sterols- $\beta$-sitosterol, stigmasterol, brassicasterol, and campesterol - and cholesterol on their impact on the molecular mechanism leading to $\mathrm{AD}$.

Our data show that plant sterols are biologically active food compounds interfering with important functional processes in the brain. In respect to Alzheimer's disease we could demonstrate that plant sterols are not as amyloidogenic as cholesterol, and that in particular stigmasterol decreases amyloidogenic processing and could therefore be an interesting food compound being beneficial in Alzheimer's disease.

However, we could also show that the underlying mechanisms, making phytosterols an interesting target for Alzheimer's disease, also affect membrane organization like cholesterol-enriched lipid raft membrane microdomains and endocytosis, which might also be relevant for other brain functions. Therefore, we cannot exclude that plant sterols might interfere with further critical lipid raft membrane functions, including cell signaling, neurotransmission, and membrane protein trafficking (Tsui-Pierchala et al., 2002), which should be addressed by further studies.

\section{References}

Abrami L, Liu S, Cosson P, Leppla SH, van der Goot FG (2003) Anthrax toxin triggers endocytosis of its receptor via a lipid raft-mediated clathrindependent process. J Cell Biol 160:321-328. CrossRef Medline

Acuff RV, Cai DJ, Dong ZP, Bell D (2007) The lipid lowering effect of plant sterol ester capsules in hypercholesterolemic subjects. Lipids Health Dis 6:11. CrossRef Medline

Berger A, Jones PJ, Abumweis SS (2004) Plant sterols: factors affecting their efficacy and safety as functional food ingredients. Lipids Health Dis 3:5. CrossRef Medline

Bligh EG, Dyer WJ (1959) A rapid method of total lipid extraction and purification. Can J Biochem Physiol 37:911-917. CrossRef Medline

Calpe-Berdiel L, Escolà-Gil JC, Blanco-Vaca F (2009) New insights into the molecular actions of plant sterols and stanols in cholesterol metabolism. Atherosclerosis 203:18-31. CrossRef Medline

Corder EH, Saunders AM, Strittmatter WJ, Schmechel DE, Gaskell PC, Small GW, Roses AD, Haines JL, Pericak-Vance MA (1993) Gene dose of apolipoprotein E type 4 allele and the risk of Alzheimer's disease in late onset families. Science 261:921-923. CrossRef Medline

De Strooper B (2003) Aph-1, Pen-2, and Nicastrin with Presenilin generate an active gamma-Secretase complex. Neuron 38:9-12. CrossRef Medline

Duff RB (1949) Carbohydrate sulphuric esters. Part V. The demonstration of Walden inversion on hydrolysis of barium 1:6-anhydro-beta-Dgalactose 2-sulfate. J Am Chem Soc 1597-1600.

Dufourc EJ (2008) Sterols and membrane dynamics. J Chem Biol 1:63-77. CrossRef Medline

Ehehalt R, Keller P, Haass C, Thiele C, Simons K (2003) Amyloidogenic processing of the Alzheimer beta-amyloid precursor protein depends on lipid rafts. J Cell Biol 160:113-123. CrossRef Medline

Fassbender K, Simons M, Bergmann C, Stroick M, Lutjohann D, Keller P, Runz H, Kuhl S, Bertsch T, von Bergmann K, Hennerici M, Beyreuther K, Hartmann T (2001) Simvastatin strongly reduces levels of Alzheimer's disease beta-amyloid peptides Abeta 42 and Abeta 40 in vitro and in vivo. Proc Natl Acad Sci U S A 98:5856-5861. CrossRef Medline

Ghribi O, Larsen B, Schrag M, Herman MM (2006) High cholesterol content in neurons increases BACE, beta-amyloid, and phosphorylated tau levels in rabbit hippocampus. Exp Neurol 200:460-467. CrossRef Medline

Glenner GG, Wong CW (1984) Alzheimer's disease: initial report of the purification and characterization of a novel cerebrovascular amyloid protein. Biochem Biophys Res Commun 120:885-890. CrossRef Medline

González-Larena M, García-Llatas G, Vidal MC, Sánchez-Siles LM, Barberá R, Lagarda MJ (2011) Stability of plant sterols in ingredients used in functional foods. J Agric Food Chem 59:3624-3631. CrossRef Medline

Grimm HS, Beher D, Lichtenthaler SF, Shearman MS, Beyreuther K, Hartmann T (2003) gamma-Secretase cleavage site specificity differs for intracellular and secretory amyloid beta. J Biol Chem 278:13077-13085. CrossRef Medline

Grimm MO, Grimm HS, Pätzold AJ, Zinser EG, Halonen R, Duering M, Tschäpe JA, De Strooper B, Müller U, Shen J, Hartmann T (2005) Regulation of cholesterol and sphingomyelin metabolism by amyloid-beta and presenilin. Nat Cell Biol 7:1118-1123. CrossRef Medline

Grimm MO, Kuchenbecker J, Rothhaar TL, Grösgen S, Hundsdörfer B, Burg VK, Friess P, Müller U, Grimm HS, Riemenschneider M, Hartmann T (2011a) Plasmalogen synthesis is regulated via alkyl-dihydroxyacetonephosphate-synthase by amyloid precursor protein processing and is affected in Alzheimer's disease. J Neurochem 116:916-925. CrossRef Medline

Grimm MO, Kuchenbecker J, Grösgen S, Burg VK, Hundsdörfer B, Rothhaar TL, Friess P, de Wilde MC, Broersen LM, Penke B, Péter M, Vígh L, Grimm HS, Hartmann T (2011b) Docosahexaenoic acid reduces amyloid beta production via multiple pleiotropic mechanisms. J Biol Chem 286:14028-14039. CrossRef Medline

Grimm MO, Rothhaar TL, Grösgen S, Burg VK, Hundsdörfer B, Haupenthal VJ, Friess P, Kins S, Grimm HS, Hartmann T (2012) Trans fatty acids enhance amyloidogenic processing of the Alzheimer amyloid precursor protein (APP). J Nutr Biochem 23:1214-1223. CrossRef Medline

Gunstone FD, Harwood JL, Padley FB (1994) The lipid handbook, second edition. London: Chapman and Hall.

Hansen GH, Dalskov SM, Rasmussen CR, Immerdal L, Niels-Christiansen LL, Danielsen EM (2005) Cholera toxin entry into pig enterocytes occurs via a lipid raft- and clathrin-dependent mechanism. Biochemistry 44:873-882. CrossRef Medline

Herreman A, Serneels L, Annaert W, Collen D, Schoonjans L, De Strooper B (2000) Total inactivation of gamma-secretase activity in presenilindeficient embryonic stem cells. Nat Cell Biol 2:461-462. CrossRef Medline

Huse JT, Pijak DS, Leslie GJ, Lee VM, Doms RW (2000) Maturation and endosomal targeting of beta-site amyloid precursor protein-cleaving enzyme. The Alzheimer's disease beta-secretase. J Biol Chem 275:3372933737. CrossRef Medline

Ida N, Hartmann T, Pantel J, Schröder J, Zerfass R, Förstl H, Sandbrink R, Masters CL, Beyreuther K (1996) Analysis of heterogeneous A4 peptides in human cerebrospinal fluid and blood by a newly developed sensitive Western blot assay. J Biol Chem 271:22908-22914. CrossRef Medline

Kimberly WT, LaVoie MJ, Ostaszewski BL, Ye W, Wolfe MS, Selkoe DJ (2003) Gamma-secretase is a membrane protein complex comprised of presenilin, nicastrin, Aph-1, and Pen-2. Proc Natl Acad Sci U S A 100: 6382-6387. CrossRef Medline

Kivipelto M, Helkala EL, Laakso MP, Hänninen T, Hallikainen M, Alhainen K, Soininen H, Tuomilehto J, Nissinen A (2001) Midlife vascular risk factors and Alzheimer's disease in later life: longitudinal, population based study. BMJ 322:1447-1451. CrossRef Medline

Kojro E, Gimpl G, Lammich S, Marz W, Fahrenholz F (2001) Low cholesterol stimulates the nonamyloidogenic pathway by its effect on the alphasecretase ADAM 10. Proc Natl Acad Sci U S A 98:5815-5820. CrossRef Medline

Kölsch H, Heun R, Jessen F, Popp J, Hentschel F, Maier W, Lütjohann D (2010) Alterations of cholesterol precursor levels in Alzheimer's disease. Biochim Biophys Acta 1801:945-950. CrossRef Medline

Lechner M, Reiter B, Lorbeer E (1999) Determination of tocopherols and sterols in vegetable oils by solid-phase extraction and subsequent capillary gas chromatographic analysis. J Chromatogr A 857:231-238. CrossRef Medline 
Lemkul JA, Bevan DR (2011) Lipid composition influences the release of Alzheimer's amyloid beta-peptide from membranes. Protein Sci 20: 1530-1545. CrossRef Medline

Liu WW, Todd S, Coulson DT, Irvine GB, Passmore AP, McGuinness B, McConville M, Craig D, Johnston JA (2009) A novel reciprocal and biphasic relationship between membrane cholesterol and betasecretase activity in SH-SY5Y cells and in human platelets. J Neurochem 108:341-349. CrossRef Medline

Marquer C, Devauges V, Cossec JC, Liot G, Lécart S, Saudou F, Duyckaerts C, Lévêque-Fort S, Potier MC (2011) Local cholesterol increase triggers amyloid precursor protein-Bace1 clustering in lipid rafts and rapid endocytosis. FASEB J 25:1295-1305. CrossRef Medline

Mongrand S, Morel J, Laroche J, Claverol S, Carde JP, Hartmann MA, Bonneu M, Simon-Plas F, Lessire R, Bessoule JJ (2004) Lipid rafts in higher plant cells: purification and characterization of Triton X-100-insoluble microdomains from tobacco plasma membrane. J Biol Chem 279:3627736286. CrossRef Medline

Mongrand S, Stanislas T, Bayer EM, Lherminier J, Simon-Plas F (2010) Membrane rafts in plant cells. Trends Plant Sci 15:656-663. CrossRef Medline

Normen L, Bryngelsson S, Johnsson M, Evheden P, Ellegard L, Brants H, Andersson H, Dutta P (2002) The phytosterol content of some cereal foods commonly consumed in Sweden and in The Netherlands. J Food Compost Anal 15:693-704. CrossRef

Osenkowski P, Ye W, Wang R, Wolfe MS, Selkoe DJ (2008) Direct and potent regulation of gamma-secretase by its lipid microenvironment. J Biol Chem 283:22529-22540. CrossRef Medline

Ostlund RE Jr (2002) Phytosterols in human nutrition. Annu Rev Nutr 22: 533-549. CrossRef Medline

Parks AL, Curtis D (2007) Presenilin diversifies its portfolio. Trends Genet 23:140-150. CrossRef Medline

Parr-Sturgess CA, Rushton DJ, Parkin ET (2010) Ectodomain shedding of the Notch ligand Jagged 1 is mediated by ADAM17, but is not a lipid-raftassociated event. Biochem J 432:283-294. CrossRef Medline

Parsons RB, Subramaniam D, Austen BM (2007) A specific inhibitor of cholesterol biosynthesis, BM15.766, reduces the expression of betasecretase and the production of amyloid-beta in vitro. J Neurochem 102: 1276-1291. CrossRef Medline

Phillips KM, Ruggio DM, Toivo JI, Swank MA, Simpkins AH (2002) Free and esterified sterol composition of edible oils and fats. J Food Compost Anal 15:123-142. CrossRef

Piironen V, Lindsay DG, Miettinen TA, Toivo J, Lampi AM (2000) Plant sterols: biosynthesis, biological function and their importance to human nutrition. J Sci Food Agric 80:939-966. CrossRef

Plat J, Mensink RP (2001) Effects of plant sterols and stanols on lipid metabolism and cardiovascular risk. Nutr Metab Cardiovasc Dis 11:31-40. Medline

Probst G, Aubele DL, Bowers S, Dressen D, Garofalo AW, Hom RK, Konradi AW, Marugg JL, Mattson MN, Neitzel ML, Semko CM, Sham HL, Smith J, Sun M, Truong AP, Ye XM, Xu YZ, Dappen MS, Jagodzinski JJ, Keim PS, et al. (2013) Discovery of ( $R$ )-4-Cyclopropyl-7,8-difluoro-5-(4-(trifluoromethyl)phenylsulfonyl)-4,5-dihydro-1 $H$-pyrazolo[4,3-c] quinoline (ELND006) and ( $R$ )-4Cyclopropyl-8-fluoro-5-(6-(trifluoromethyl)pyridin-3-ylsulfonyl)-4,5-dihydr o-2 $\mathrm{H}$-pyrazolo[4,3-c]quinoline (ELND007): metabolically stable gammasecretase inhibitors that selectively inhibit the production of amyloid-beta over notch. Advance online publication. Retrieved June 20, 2103. J Med Chem. doi: 10.1021/jm301741t. CrossRef Medline

Puglielli L, Tanzi RE, Kovacs DM (2003) Alzheimer's disease: the cholesterol connection. Nat Neurosci 6:345-351. CrossRef Medline

Reeves PG, Nielsen FH, Fahey GC Jr (1993) AIN-93 purified diets for laboratory rodents: final report of the American Institute of Nutrition ad hoc writing committee on the reformulation of the AIN-76A rodent diet. J Nutr 123:1939-1951. Medline

Refolo LM, Malester B, LaFrancois J, Bryant-Thomas T, Wang R, Tint GS, Sambamurti K, Duff K, Pappolla MA (2000) Hypercholesterolemia accelerates the Alzheimer's amyloid pathology in a transgenic mouse model. Neurobiol Dis 7:321-331. CrossRef Medline

Refolo LM, Pappolla MA, LaFrancois J, Malester B, Schmidt SD, ThomasBryant T, Tint GS, Wang R, Mercken M, Petanceska SS, Duff KE (2001) A cholesterol-lowering drug reduces beta-amyloid pathology in a transgenic mouse model of Alzheimer's disease. Neurobiol Dis 8:890-899. CrossRef Medline
Richelle M, Enslen M, Hager C, Groux M, Tavazzi I, Godin JP, Berger A, Métairon S, Quaile S, Piguet-Welsch C, Sagalowicz L, Green H, Fay LB (2004) Both free and esterified plant sterols reduce cholesterol absorption and the bioavailability of beta-carotene and alpha-tocopherol in normocholesterolemic humans. Am J Clin Nutr 80:171-177. Medline

Riddell DR, Christie G, Hussain I, Dingwall C (2001) Compartmentalization of beta-secretase (Asp2) into low-buoyant density, noncaveolar lipid rafts. Curr Biol 11:1288-1293. CrossRef Medline

Rodal SK, Skretting G, Garred O, Vilhardt F, van Deurs B, Sandvig K (1999) Extraction of cholesterol with methyl-beta-cyclodextrin perturbs formation of clathrin-coated endocytic vesicles. Mol Biol Cell 10:961-974. CrossRef Medline

Rohan de Silva HA, Jen A, Wickenden C, Jen LS, Wilkinson SL, Patel AJ (1997) Cell-specific expression of beta-amyloid precursor protein isoform mRNAs and proteins in neurons and astrocytes. Brain Res Mol Brain Res 47:147-156. CrossRef Medline

Rollason R, Korolchuk V, Hamilton C, Schu P, Banting G (2007) Clathrinmediated endocytosis of a lipid-raft-associated protein is mediated through a dual tyrosine motif. J Cell Sci 120:3850-3858. CrossRef Medline

Sakurai T, Kaneko K, Okuno M, Wada K, Kashiyama T, Shimizu H, Akagi T, Hashikawa T, Nukina N (2008) Membrane microdomain switching: a regulatory mechanism of amyloid precursor protein processing. J Cell Biol 183:339-352. CrossRef Medline

Schwartz H, Ollilainen V, Piironen V, Lampi AM (2008) Tocopherol, tocotrienol and plant sterol contents of vegetable oils and industrial fats. J Food Compost Anal 21:152-161. CrossRef

Shearman MS, Beher D, Clarke EE, Lewis HD, Harrison T, Hunt P, Nadin A, Smith AL, Stevenson G, Castro JL (2000) L-685,458, an aspartyl protease transition state mimic, is a potent inhibitor of amyloid betaprotein precursor gamma-secretase activity. Biochemistry 39:86988704. CrossRef Medline

Shie FS, Jin LW, Cook DG, Leverenz JB, LeBoeuf RC (2002) Diet-induced hypercholesterolemia enhances brain A beta accumulation in transgenic mice. Neuroreport 13:455-459. CrossRef Medline

Simons K, Ikonen E (1997) Functional rafts in cell membranes. Nature 387: 569-572. CrossRef Medline

Sinha S, Anderson JP, Barbour R, Basi GS, Caccavello R, Davis D, Doan M, Dovey HF, Frigon N, Hong J, Jacobson-Croak K, Jewett N, Keim P, Knops J, Lieberburg I, Power M, Tan H, Tatsuno G, Tung J, Schenk D, Seubert P, Suomensaari SM, Wang S, Walker D, Zhao J, McConlogue L, John V (1999) Purification and cloning of amyloid precursor protein betasecretase from human brain. Nature 402:537-540. CrossRef Medline

Sisodia SS, St George-Hyslop PH (2002) gamma-Secretase, Notch, Abeta and Alzheimer's disease: where do the presenilins fit in? Nat Rev Neurosci 3:281-290. CrossRef Medline

Smith PK, Krohn RI, Hermanson GT, Mallia AK, Gartner FH, Provenzano MD, Fujimoto EK, Goeke NM, Olson BJ, Klenk DC (1985) Measurement of protein using bicinchoninic acid. Anal Biochem 150:76-85. CrossRef Medline

Stoddart A, Dykstra ML, Brown BK, Song W, Pierce SK, Brodsky FM (2002) Lipid rafts unite signaling cascades with clathrin to regulate BCR internalization. Immunity 17:451-462. CrossRef Medline

Subtil A, Gaidarov I, Kobylarz K, Lampson MA, Keen JH, McGraw TE (1999) Acute cholesterol depletion inhibits clathrin-coated pit budding. Proc Natl Acad Sci U S A 96:6775-6780. CrossRef Medline

Teunissen CE, De Vente J, von Bergmann K, Bosma H, van Boxtel MP, De Bruijn C, Jolles J, Steinbusch HW, Lütjohann D (2003) Serum cholesterol, precursors and metabolites and cognitive performance in an aging population. Neurobiol Aging 24:147-155. CrossRef Medline

Thirumangalakudi L, Prakasam A, Zhang R, Bimonte-Nelson H, Sambamurti K, Kindy MS, Bhat NR (2008) High cholesterol-induced neuroinflammation and amyloid precursor protein processing correlate with loss of working memory in mice. J Neurochem 106:475-485. CrossRef Medline

Tsui-Pierchala BA, Encinas M, Milbrandt J, Johnson EM Jr (2002) Lipid rafts in neuronal signaling and function. Trends Neurosci 25:412-417. CrossRef Medline

Vance JE, Hayashi H, Karten B (2005) Cholesterol homeostasis in neurons and glial cells. Semin Cell Dev Biol 16:193-212. CrossRef Medline

Vanmierlo T, Weingärtner O, van der Pol S, Husche C, Kerksiek A, Friedrichs S, Sijbrands E, Steinbusch H, Grimm M, Hartmann T, Laufs U, Böhm M, 
de Vries HE, Mulder M, Lütjohann D (2012) Dietary intake of plant sterols stably increases plant sterol levels in the murine brain. J Lipid Res 53:726-735. CrossRef Medline

Vassar R, Bennett BD, Babu-Khan S, Kahn S, Mendiaz EA, Denis P, Teplow DB, Ross S, Amarante P, Loeloff R, Luo Y, Fisher S, Fuller J, Edenson S, Lile J, Jarosinski MA, Biere AL, Curran E, Burgess T, Louis JC, Collins F, Treanor J, Rogers G, Citron M (1999) Beta-secretase cleavage of Alzheimer's amyloid precursor protein by the transmembrane aspartic protease BACE. Science 286:735-741. CrossRef Medline

Vetrivel KS, Thinakaran G (2010) Membrane rafts in Alzheimer's disease beta-amyloid production. Biochim Biophys Acta 1801:860-867. CrossRef Medline

Wahrle S, Das P, Nyborg AC, McLendon C, Shoji M, Kawarabayashi T, Younkin LH, Younkin SG, Golde TE (2002) Cholesterol-dependent gamma-secretase activity in buoyant cholesterol-rich membrane microdomains. Neurobiol Dis 9:11-23. CrossRef Medline

Weihrauch JL, Gardner JM (1978) Sterol content of foods of plant origin. J Am Diet Assoc 73:39-47. Medline

Willem M, Garratt AN, Novak B, Citron M, Kaufmann S, Rittger A, DeStrooper B, Saftig P, Birchmeier C, Haass C (2006) Control of pe- ripheral nerve myelination by the beta-secretase BACE1. Science 314: 664-666. CrossRef Medline

Wolozin B (2001) A fluid connection: cholesterol and Abeta. Proc Natl Acad Sci U S A 98:5371-5373. CrossRef Medline

Wong HK, Sakurai T, Oyama F, Kaneko K, Wada K, Miyazaki H, Kurosawa M, De Strooper B, Saftig P, Nukina N (2005) beta Subunits of voltagegated sodium channels are novel substrates of beta-site amyloid precursor protein-cleaving enzyme (BACE1) and gamma-secretase. J Biol Chem 280:23009-23017. CrossRef Medline

Woods AJ, White DP, Caswell PT, Norman JC (2004) PKD1/PKCmu promotes alphavbeta 3 integrin recycling and delivery to nascent focal adhesions. EMBO J 23:2531-2543. CrossRef Medline

Xiong H, Callaghan D, Jones A, Walker DG, Lue LF, Beach TG, Sue LI, Woulfe J, Xu H, Stanimirovic DB, Zhang W (2008) Cholesterol retention in Alzheimer's brain is responsible for high beta- and gammasecretase activities and Abeta production. Neurobiol Dis 29:422-437. CrossRef Medline

Yang LB, Lindholm K, Yan R, Citron M, Xia W, Yang XL, Beach T, Sue L, Wong P, Price D, Li R, Shen Y (2003) Elevated beta-secretase expression and enzymatic activity detected in sporadic Alzheimer disease. Nat Med 9:3-4. CrossRef Medline 